DIVISION OF THE HUMANITIES AND SOCIAL SCIENCES

CALIFORNIA INSTITUTE OF TECHNOLOGY

PASADENA, CALIFORNIA 91125

BANKING INDUSTRY STRUCTURE, COMPETITION, AND

PERFORMANCE: DOES UNIVERSALITY MATTER?

Caroline Fohlin

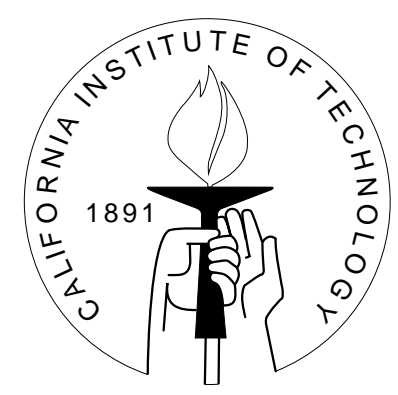

SOCIAL SCIENCE WORKING PAPER 1078

October 2000 


\title{
Banking Industry Structure, Competition, and Performance: Does Universality Matter?
}

\author{
Caroline Fohlin*
}

Draft: October, 2000

\begin{abstract}
By studying the German universal banking system in the pre-World War I period, in comparison with its American and British counterparts, this paper investigates whether universality (the combination of commercial and investment banking services) influences banking industry concentration, levels of market power, or financial performance of banks. The short answer is "no." First, given that the UK's specialized commercial banking sector was structured very similarly to the German universal industrial banking sector, and that neither system was extremely concentrated in the pre-war era, the paper argues that universality does not necessarily or uniquely propagate concentration. Second, on average, German universal banks behaved no less competitively than their American counterparts in the provision of loan services. Structural price markup models, as well as reduced-form Rosse-Panzar tests, demonstrate little deviation from competitive pricing in either country. The findings therefore indicate that universality does not lead to appreciable market power, in either an absolute or a relative sense. These same results also imply that banking industry concentration, at least up to the moderately high levels found in Germany, does not in itself produce anti-competitive behavior. The empirical results, though contradictory to common wisdom about German universal banking, are easily motivated by the theoretical literature in industrial organization. Finally, estimates of returns on equity and on assets suggest only slight international differences in average returns over extended periods, but large deviations in individual years. Adjusting for prevailing rates on government bonds, commercial loans, or commercial deposits narrows the gaps further. Universality is not linked with superior profitability, whether the hypothesized source is efficiency (economies of scope) or monopoly power. These three sets of findings may assuage fears that deregulation in American banking could lead to excessive concentration and therefore collusive behavior. At the same time, the results may lower hopes of significant efficiency gains from broadening the scope of services.
\end{abstract}

"Mailcode 228-77, California Institute of Technology, Pasadena, CA 91125. E-mail: fohlin@ @ss.caltech.edu. http://hss.caltech.edu/ fohlin. Thanks are due to Peter Bossaerts, John Latting, and Simon Wilkie for helpful discussions. I am grateful to Pei-Hua Hung, Jean Kim, Yong Kim, Jin Li, and Ernest Young for their energetic research assistance. 


\section{Banking Industry Structure, Competition, and Performance: Does Universality Matter?}

Recent waves of banking mergers and continuing liberalization of banking regulations in the United States have raised questions and concerns about the competitiveness of the American banking system and prospects for its performance in the future. The dismantling of the Glass-Steagall Act of 1933, permitting even greater scope in the provision of financial services in individual institutions, may spur industry consolidation and the creation of universal banks similar to those found in Germany and several other continental European countries.

American economists and regulators have long associated industry concentration with market power, anti-competitive practices, and social welfare losses; though more recent ideas of market contestability have partly assuaged those fears. Despite prolific research in the area, however, we still have an incomplete understanding of the relationship between banking concentration and market power. We have even less knowledge of the impact of financial system design on industry structure and performance. There are several issues that need resolving: for example, whether universal banking naturally leads to banking industry concentration or to market power, and whether banking institution design affects the financial structure and performance of individual banks. The current paper offers insights on these problems by studying the German universal banking system in the pre-World War I period, in comparison with its American and British counterparts.

Germany has long provided the paradigm case of universal banking; having been one of the first and most enthusiastic developers of large scale, joint-stock, mixed banks. Benston (1994, p.121), for example, has noted that, "Germany today and before the second World War offers the best example of universal banking." Similar financial institutions emerged in other continental European countries, but the German incarnation has come virtually to define universal banking. The British deposit banks and American commercial banks provide the classic counterpoints to the German universal banks, but even the two Anglophone systems differ significantly. At least in the decades leading up to World War I, the British financial system was the most specialized. By contrast, at the start of the twentieth century, the American banks were actually quasi-universal, since most significant investment houses maintained commercial bank affiliates, usually as subsidiaries. 
Historical evidence is particularly useful for investigating institutional design. A long-run perspective allows insights into the roots of modern institutions, the persistence of certain organizational forms, and the sometimes dramatic changes that also take place. Past experience may also inform modern problems. For example, despite the development of universal banks in Germany, securities markets flourished in that country from the 1870 s until the inter-war years. During this period, universal banks providing commercial, investment, and brokerage services operated alongside active security markets offering trading in stocks and bonds. The American corporate financial system could begin to take something of this shape in the early $21^{\text {st }}$ century. The fact that the German and British commercial banks enjoyed relatively little regulatory intervention in the 1880-1913 period, yet maintained quite different organizational structure, makes for a another useful comparison. Moreover, the amalgamation movements in Germany and the UK, continuing from the 1890s into the inter-war years, could foreshadow changes in the American banking industry in the years to come. Thus, historical research on the German, American, and British systems may prove highly informative for current debates over structure and performance in the American banking system.

To address the overarching question of financial system design and banking sector outcomes, the remainder of the paper pursues several lines of analysis. In order to draw conclusions about the importance of institutional design, it is necessary to have a typology in mind. Thus, the first task of the paper is to clarify organizational differences among the three systems considered. Subsequent sections then investigate the possible impact of financial system design in three areas of concern to the banking sector: industrial organization, extent of market power, and financial performance. The final section concludes and discusses the modern implications of the historical findings.

\section{FINANCIAL SYSTEM STRUCTURE: U NIVERSALITY VERSUS SPECIALIZATION}

The extant work on financial system design and banking industry structure poses a wide range of hypotheses-formal and informal-regarding the relationship among product scope of banking institutions, market orientation of the financial system generally, and industrial organization of the banking sector in particular. The following sets out several common notions about financial system structure and confronts them with evidence from Germany, the United States, and the United Kingdom. 
1. Universality of banks is associated with bank domination; specialized banking is associated with market-orientation. ${ }^{1}$ That is, the supposed dichotomy between banks and markets is equated with a second dichotomy between universal banking and specialized banking. It is unclear whether underdeveloped markets cause (necessitate) universality or stem from it (banks subsume market functions): both arguments are made. In the former case, universality is viewed as a second-best solution in the absence of markets; in the latter case, universality is seen as an improvement over markets.

2. Universal banks are large compared to specialized banks. ${ }^{2}$ Again, the direction of causality is dual: minimum efficient scale may be larger for a universal bank, or universality may simply offer greater opportunities for a bank to grow. Calomiris $(1995,2000)$ has argued very specifically that size constraints prevented American banks from becoming universal. Historical evidence is particularly useful for addressing these issues, since the evidence comes from the formative decades of the universal banking system.

3. Universality requires branching. The link between universality and branching is size, so this hypothesis is really a corollary of the previous hypothesis. That is, universality is seen as hinging on size, and size is viewed as contingent upon gathering resources through branching networks. Thus, if size does not require branching, then universality will not either. Of course, even if size does entail branching, hypothesis 2 may still prove false (if universality can emerge without large scale).

4. Universality leads to banking industry concentration. This hypothesis also stems partly from hypothesis two. For a given set of available financial resources, the need for size should naturally lead to the creation of fewer institutions. There are certain circumstances, however, in which this link would be undermined: if the organization of banks affects the size of a country's overall pool of resources or the division of resources among the various segments of the financial services industry. For example, if universal banks are able to mobilize more capital than their specialized counterparts, then the corporate banking sector will be larger and the need for large scale may not produce particularly high concentration. On the other hand, if universality is associated with segmentation in the deposit market and therefore a more constrained set of resources available to the corporate sector, then the hypothesized need for large scale will create clearly.

${ }^{1}$ For a more comprehensive discussion, see Fohlin (1999b, 2000). Dietl (1998) lays out the idealized dichotomy very

${ }^{2}$ See Calomiris (1995) on this and the following hypothesis. 
concentration. Thus, despite its prevalence in the historical literature, there is rather weak theoretical grounding for this hypothesis.

\section{Hypothesis 1: types of financial systems}

The phrase 'universal banking' is often used as if it were a well-defined and static principle. In reality, the practices considered part of this style of banking vary among users of the term and have also changed over time. The fundamental characteristic of universal banking is the joint provision of a wide range of financial services by the same institution: true universal banks are allowed to provide virtually any product. These supermarkets of corporate finance typically combine standard commercial banking functions (short-term credit, deposit taking, payments clearing, bill discounting) with investment services (underwriting and placing equities and bonds) and securities brokerage. Modern universal banks also sell insurance, mortgages, and investment funds, though they usually do so through affiliates. Universal banking should be distinguished from relationship banking. Primary examples of the latter include holding equity stakes, voting shares in proxy for customers, and sitting on the boards of directors or supervisory boards of client firms. Not all universal banks perform the complete range of relationship banking functions, and not all financial institutions that engage in relationships are universal banks.

Economists often categorize banking systems as either universal or specialized; the British and American systems typically exemplify the latter type. While specialized banking in the U.S. is assumed to be the result of regulatory constraints, not all specialized systems result from prohibitions on universality: British commercial banks, for example, have always been permitted to engage in universal and relationship banking, but have (until very recently) refrained. In practice, most systems defy crisp classification; and some have also changed significantly over time (Fohlin, 2000).

The idea of universality applies mostly to corporate financial services, so that countries with universal banks may actually maintain as wide a variety of financial institutions as those with specialized banking. For example, Germany and the U.K. had nearly the same number of different types of institutions in both 1880 and 1910, while the U.S. had fewer than either of the two European countries in both years (Table 1). Similarly, though many associate universality of corporate banking institutions with bank domination of the financial system, there is no quantitative evidence for such an association historically: the U.S. and U.K. 
commercial banks held a much larger percentage of financial institution assets than did the German universal banks in both 1880 and 1913. The flip side of the coin-that universality tends to crowd out securities markets-also appears to be false. The available data on stock market size-market capitalization as a share of GDP-suggests that the German stock exchanges, though much smaller than their British counterparts, were much larger than the American exchanges. The order is reversed for domestic securities issued as a percentage of GNP, meaning that Germany's universal system was still in the middle between the two more specialized systems. Perhaps even more striking is the finding that the American commercial banks' assets amounted to a much higher percentage of stock market capitalization than did the German universal banks. At the same time, the UK banks' assets were much smaller as a share of stock market capitalization-likely because of London's role as the world's financial center prior to World War I.

Clearly, while there may be some correlation between universality and lack of market orientation, the first hypothesis fails as a general principle. This failure is important to bear in mind in constructing comparisons of financial systems. If financial systems may not be categorized neatly, then differences in performance may not stem from variation in institutional design. This problem makes it all the more useful to include both the US and the UK as examples of specialized banking.

\section{Hypotheses 2 and 3: banking scale and branching}

For both conceptual and practical reasons, it is difficult to compare banking industries internationally. First, since German banks are universal, the category of commercial banks also subsumes investment banks, discount houses, and brokerage firms that fall into separate categories in Britain and the United States. Second, for many classes of institutions and for private banks in particular, data are sparse and relatively rough. Nonetheless, useful comparisons may be made (Table 2).

The first point is the lack of support for hypothesis two. Without some quantification of minimum efficient scale for specialized versus universal banks, we can only determine whether size is associated with universality and whether scale restrictions constrained American banks (in the period before explicit constraints on scope). The average size of banks varied wildly among the three countries. While it is true that the specialized American banks were far behind the German universal banks in terms of average assets per bank, U.K. banks on average owned almost three times the assets of their German counterparts in 1890, 
1900, and 1910. Given that the specialized commercial banks of the U.K. were on average the largest by far, it is clear that size does not beget universality. This fact does not necessarily mean that universality does not require size, but it does suggest that the German banks were not overly large at this time. Other pieces of evidence support this idea. First, the German banks were very small at their inception in the 1850's and in 1910 were still smaller than the UK deposit banks had been in 1890. Second, there were many banks in the US in this period that were both on par with the average German banks and were far larger than the vast majority of American banks. Finally, quite a few universal banks in Germany were smaller than many American banks; so, even if American banks were as large as they could be given existing restrictions, it appears that the minimum efficient scale for universal banking was not the crucial roadblock for at least some American banks to become universal. ${ }^{3}$ Thus, universality is not inextricably linked to size, as either cause or effect.

Still, it is obvious that American banks were overall relatively small, and size constraints did produce a large number of banks in the U.S. compared to Germany and Great Britain. In 1900, for example, commercial banks numbered 12,427 (3,731 national and 8,696 non-national). ${ }^{4}$ The figures for Germany and the U.K. vary substantially depending on the source and on the inclusion of private bankers in Germany. Official figures for Germany (Deutsche Bundesbank, 1976), the only that I know of, put the count of jointstock banks at 71 in the 1880 's. Donaubauer (1988) estimates that over 2,000 private bankers operated in Germany in the 1890's, while the Deutsche Bundesbank (1976) estimates around 1,100 for 1913. In addition, Pohl (1982) suggests that there were about 1,500 such banks at the time of the formation of the German Empire in 1871. Population per bank may allow a more informative international comparison of the proliferation of such institutions; the results are quite interesting. ${ }^{5}$ For example, in 1890, there were over two

${ }^{3}$ If the German private banks are included (using the estimate of 2,000 such banks in 1900, for example), the figures for Germany would drop dramatically-to about 1.5 million 1913 dollars average assets per bank (compared to just short of 900 thousand for the American commercial banks and 43 million 1913 dollars for the British banks). In addition, it is worth noting that Italian banks were also universal in many cases but were much smaller than the German universal banks. So, there were even more American banks that were the same size or larger than Italian universal banks-further suggesting that many American banks were sufficiently large to operate as universal banks.

${ }^{4}$ Board of Governors of the Federal Reserve (1959) and U.S. Bureau of the Census (1960).

${ }^{5}$ For the U.K., Shepard (1971, based on the Economist's reports) estimates far fewer banks than do Capie and Weber (1985). The latter figures are almost certainly superior to the former and are therefore used where possible. Since Capie and Weber report only deposits, not total assets, for their banks, Table 2 uses the Shepard figures to calculate average assets per 
and a half times as many people per bank in Germany as there were in the U.K., yet by 1910, there was over 50 percent more population per institution in the latter country than in the former.

Branching is another story. In the U.K., the branch network covered the country much earlier than in Germany. Banks averaged 30 branches apiece in 1890, 45 in 1900, and 93 in 1910. Of course, population grew, and many branches were formed out of previously independent banks. Thus, the availability of banking offices to the population increased less than the figures on branching per institution might imply. Still, there were about 8,000 people per U.K. branch in 1890 and only 5,500 per branch by 1910 .

In contrast, Germany developed branching much later, despite the absence of prohibitions on such practices. Hardly any branches existed in that country until the 1870 's, at which point the newly founded Deutsche Bank began a campaign to build a network. In fact, Deutsche Bank was an outlier for decades, since (near) unit banking persisted in Germany until the turn of the twentieth century. ${ }^{6}$ In 1890 , less than a quarter of Berlin listed banks maintained branches, and even the branching banks averaged only two subsidiary offices each. Even by 1900, German joint-stock credit banks averaged only one branch apiece overall (four, if only those with branches are considered). These numbers quadrupled over the ensuing decade. While the boom in branching in Germany, as in the UK, stemmed partly from takeovers of existing institutions, the increased penetration of banking offices was dramatic nonetheless. Population per branch in Germany declined from 45,000 in 1900 to under 15,000 in 1910. If private banks are included, using a rough estimate of 1,500 single-office institutions, the figure for population per branch would fall to 9,200 people per office in 1910.

Of course, due to widespread limitations on branching, there was a negligible number of bank branches in the U.S. throughout the period. Some states, notably California, did permit intra-state branching, and banks increasingly took advantage of their freedom. Even with the near absence of branching, the trend toward increasing bank availability extended to the US as well. The overall population per banking office declined from 6,300 in 1890 to 3,700 in 1910.

bank. To the extent that the Shepard data misses primarily the smallest banks, the resulting estimate will be too high. On the other hand, as previously noted, given the exclusion of what could be thousands of private banks in Germany, those figures are also overestimated. Moreover, many more banks are reported in the Handbuch der deutschen Aktiengesellschaften in 1900 than in Deutsche Bundesbank (1976)-the source used for population per bank.

${ }^{6}$ See Fohlin (1999a). 
Taken together, the branching data for Germany, the UK, and the US reject hypothesis three. The German experience indicates that neither size nor universality requires branching in general; and the British case implies that branching (like size) does not necessarily spur universality. Specifically, since many German unit banks grew larger than American banks, it is clear that the size contrast between the American and German banks rests at least partially on factors other than branching restrictions.

\section{Hypothesis 4: banking concentration}

The results on size and proliferation of banks and branching lead naturally to the question of industry concentration. From nearly the start of universal banking in Germany commentators have remarked, sometimes with great alarm, on the concentration of economic power within the great banks. In 1910, for example, the well-known great banker Jacob Riesser proclaimed that “...the movement toward concentration precipitates itself headlong like a flood and proceeds with awful violence, as if all contrivances for stemming the tide had been swept away and all dams had been destroyed by some natural catastrophe." 7 The truth, however, may be somewhat at odds with the lore; and the phenomenon may not be linked to the universality of banking institutions. In this regard, contrasts with the United States is particularly misleading, since two of the most important incentives for concentration-geographical diversification and access to a larger deposit base-require branching. That is, if proximity to depositors is desirable, and maybe necessary, legal limits on branching prevent concentration among banks financed largely from deposits. Because the UK eliminated constraints on branching (via size limits) early in the $19^{\text {th }}$ century, that country makes for a more valuable comparison.

Concentration may be measured in a number of ways, and these different measures offer varying views of the universal banking industry over the 1884-1913 period. In the following, I construct five-firm ratios using two different balance sheet indicators (total assets and total share capital) and two different denominators (all joint-stock credit banks and the sum of such banks and private banks). The joint-stock credit banks are those termed Kreditbanken in the Deutsche Bundesbank (1976) series. Since private banks

\footnotetext{
${ }^{7} \operatorname{Riesser}(1911)$, p. 614.
} 
reported no consistent balance sheets, they are only included for total assets and then only included at estimated values.

Concentration ratios measured in this manner indicate little growth in the share of the largest banks in any of the variables used. Figure 1 plots five-firm ratios for total assets and share capital as well as greatbank ratios for total assets and deposits for 1884-1913, and Table 2 reports estimated five- and ten-firm ratios for total assets for 1890, 1900, and 1910. While the asset-based ratio increased five percentage points (to 39.6) between December 1892 and December 1894 and climbed just over 43 percent over the course of 1895 , it had remained flat in the mid-1880s and declined steadily between 1896 and 1901 (back down to 37 percent). The ratio declined on net in the latter half of the 1880s and remained around 33 to 34 percent in the early 1890s. Putting these findings together, and still ignoring the private banks, the lack of a steady trend toward concentration over the period is evident. The top five banks began the period with 37 percent of joint-stock bank assets and ended it with just short of 42 percent.

Ratios using share capital show even less growth. Though the five-firm capital ratio increased from 34 to 39 percent over the course of 1895 , the ratio had generally declined up through 1894 and continued to drop steadily between 1895 and 1901 (to a low of just over 31 percent) and then between 1904 and 1912 (from 37 to under 31 percent). The difference in results sheds some light on the relative use of capital in the expansion of joint-stock universal banks. The fact that asset concentration ratios grew relative to share capital-based ratios suggests that the largest banks (all centered in the capitol, Berlin) increased their assets more through deposits than through share capital, compared with the provincial banks. In other words, since a given volume of deposits very likely corresponds to a larger number of individual investors than an equal amount of share capital, the great banks appear to have been expanding their customer base rapidly at the expense of provincial universal banks.

These figures, however, exclude the multitudes of private bankers. It is not obvious that private bankers should be considered as part of the universal banking sector. Only a small percentage-albeit mainly the largest-of these banks competed with the joint-stock universal banks in commercial banking, brokerage, deposit-taking, or underwriting. Many served a clientele that never dealt with joint-stock universal banks. The relevant measure of universal banking concentration may therefore lie somewhere between those computed with joint-stock banks and those calculated with the sum of private and joint-stock institutions. Unfortunately, such a calculation would be extremely problematic, since there would be no way to determine 
the assets or even the existence of all private banks, much less categorize them according to their clientele and lines of business. Ratios that include (exclude) private banks do provide a lower (upper) bound on the true level of concentration.

The banking industry underwent significant organizational change over the course of the nineteenth and early twentieth centuries; with private bankers comprising a declining share of the sector, especially toward the end of the period. Private bank assets, by their nature, are difficult to count, but estimates suggest that they amounted to at least that of joint-stock banks in the 1880's but only half between 1900 and 1913. When private banks are included, the concentration ratio for total assets falls to 16 percent in 1884 but only drops to 33 percent by $1913 .{ }^{8}$ Because of the linear interpolation used in estimating private bank assets, the inclusion of the private banks smooths the decline and then rebound of the concentration ratios between 1895 and 1905. The estimated figures probably exaggerate the steadiness of the increase, but, interestingly, the sharp rise of 1892-5 and the decline of 1906-08 are both still apparent in these new ratios. Nonetheless, if the private bankers are considered (and certainly some of them should be), it is clear that concentration in universal banking increased over the period in question; but the change was likely more moderate than that perceived by contemporaries or historians.

It may come as a surprise that, according to some measures, the German universal banking sector was actually less concentrated than the English deposit banking sector over the entire period from 1884 to 1913 (Figure 1 and Table 2). ${ }^{9}$ In both countries, the largest members of the commercial/universal banking sector built up significant nationwide branching networks during this period. Such branching was often accomplished by the takeover of a smaller bank (very often a private bank) in the location of a desired branch, and this movement contributed to the concentration increases in both England and Germany. Although the branch networks grew rapidly after World War I, both countries achieved an essentially national banking system by 1913, if not earlier. As a result, while the top five banks held approximately one fifth of the total bank assets in both Germany and the U.K. in 1890, the top five held 29 and 36 percent in the two countries,

${ }^{8}$ The data come from Deutsche Bundesbank (1976) for the joint-stock banks and from Raymond W. Goldsmith (1969) for the private banks (using linear interpolation between his estimates for 1880, 1900, and 1913).

${ }^{9}$ As Table 2 and the foregoing discussion indicate, the extent of market concentration in Germany varies considerably depending on whether private banks are included. Official German data sources cover only joint-stock banks; only rough estimates of private bank assets are available. Since the British and American ratios include private banks, the discussion here uses the analogous ratio for Germany. The gap between the two ratios declines over time. 
respectively, by 1910. This comparison underscores again the lack of a generalized connection between universality and branching: the German banks were universal before they branched, and the British banks branched very actively without expanding the scope of their business. Likewise, given the differences in scope between the German and British banks, the concentration ratios demonstrate the lack of connection between universality and industry concentration. The German-British comparison also emphasizes the importance of looking beyond the U.S. in trying to understand the effects of banking specialization on institutional efficiency, market structure, and competitiveness.

It is worth noting, though, that for the US as a whole, 5 and 10-firm ratios for commercial banks increased markedly, from 3.2 and 5.6 percent to 6.5 and 9.8, respectively, between 1890 and 1900. The ratios were still the same in 1908, but then declined to 4.5 and under 7 percent by 1913 . The decline in concentration stemmed only partly from the rapid increase in the number of new banks in the industry, since the largest banks concurrently also reduced their size. Throughout the period, most of the largest banks congregated in New York, though a couple made their homes in Chicago. The top ten banks also grew unevenly over the first part of the period: the largest five constituted 58 percent of the top ten in 1890 but 67 percent from 1900 to 1913.

In the United States, of course, banks could not build a nationwide branching network due to regulatory constraints. ${ }^{10}$ Since the American market for banking services was demarcated at least by state boundaries, if not by county lines, nationwide concentration ratios are not directly comparable to those for Germany and England. State-level concentration ratios reveal the variety of structures in place across the country and the lack of a clear trend in concentration between 1900 and 1913 (Table 3). ${ }^{11}$

It appears that American state concentration ratios were actually converging somewhat, since the dispersion of ratios was narrower in 1913 than in earlier years: generally, the lowest ratios increased, while the highest ratios decreased. The first effect presumably resulted from the entry of new banks into relatively rural states. For example, Colorado's concentration dropped from 59 percent in 1900 to 36 percent 13 years

\footnotetext{
${ }^{10}$ On the U.S. banking market, see Davis (1965) and Sylla (1969). The latter offers evidence that, around the turn of the last century, country banks acted as price discriminating monopolists in their respective markets.

${ }^{11}$ Concentration ratios are calculated as the share of total state and national bank assets held by the largest five national banks. National banks were usually the largest, and their financial statements are more readily available. In future work, I will attempt to confirm the accuracy of these ratios on the basis of individual state bank data.
} 
later. Less dramatically, Missouri fell from 32 to 25 percent and Vermont from 19 to 12 percent during the same period. On the other end of the spectrum, California and Michigan increased from 10 and 12 percent to 16 and 15 percent, respectively.

Interestingly, the states with the largest banks were less concentrated than a number of states with much smaller banks. New York had five-firm ratios of 18 percent in 1900 and 1913 (but 25 percent in 1908), and Illinois had ratios of 25 percent throughout the period. Comparing Texas and California suggests the potential impact of branching. Both states were geographically large, with generally dispersed population, but with a few large metropolitan areas; and both states started the twentieth century with essentially no branching and concentration ratios between 10 and 11 percent. When California began to engage in branching, around 1907, the concentration of banking increased; it reached almost 16 percent by 1913. Texas remained a unit banking state, and its banking concentration increased by only one percentage point between 1900 and 1913.

These findings cannot prove that universality does not stimulate concentration; but the results indicate very clearly that sufficient conditions for concentration can arise in specialized systems, especially when they are unhampered by branching restrictions. Most important for the historical debates, the data reject the common notion that the disadvantage of the German universal banking system was its excessive concentration.

\section{M ARKET POWER}

The previous section demonstrated the inaccuracy of many prevalent ideas about financial system design and, in the process, revealed a number of striking similarities and differences among the three systems under consideration. Particularly noteworthy for this study is the finding that scope of services is not clearly associated with concentration. This result suggests the need to go beyond concentration measures to assess the extent of market power. Thus, this section tests a fifth hypothesis: that universality leads to an anticompetitive commercial banking industry. Evaluating this hypothesis will also help determine whether industry concentration hinders competitiveness in general.

The industrial organization literature offers a number of methods by which to test for market power. The oldest methods, still in use to some extent, are based on the idea that concentration in itself evidences 
market power. ${ }^{12}$ These structure-conduct-performance (S-C-P) tests correlate industry structure to measures of banking firms' performance, such as interest rates (prices) and profit margins. Given both the conceptual shortcomings of these methods and the mixed results of past studies, the industrial organization and banking literatures have gradually shifted attention to alternative approaches based on estimates of firms' price elasticities of revenue (Rosse-Panzar test) or on econometric modeling of structural supply and demand equations (markup tests). Both methods build on the theoretical foundation of equilibrium behavior of profitmaximizing firms. The analysis here presents results of both types, though some have recently dismissed the the Rosse-Panzar model because of the identification problems inherent in estimating such a reduced-form model.

\section{Markup Tests}

Markup tests of market power, represented recently in studies by Genesove and Mullin (1998) and Shaffer (1999), arise from one of the fundamental ideas of industrial organization theory, that profit-maximizing firms choose price or quantity based on the intersection of (perceived) marginal revenue and marginal cost. ${ }^{13}$ In other words, the extent of market power reveals itself in departures from marginal cost pricing. Thus, marginal cost (c) is a function of the oligopoly price $(\mathrm{P})$, aggregate market output $(\mathrm{Q})$, other exogenous variables, and a market power parameter $(2): \mathrm{P}+2 \mathrm{QP}^{\prime}(\mathrm{Q})=\mathrm{c}$. Theory dictates that profit maximizing firms set marginal cost equal to their perceived marginal revenue; the latter will be the industry marginal revenue in the case of perfect collusion or monopoly. Theta measures the deviation of the perceived marginal revenue function from the demand schedule or, in other words, the marginal responsiveness of price to demand shocks. In theory, then, this market power parameter ranges between 0 (for perfect competition) and 1 (for perfect collusion or monopoly). In the cases of symmetric Cournot competition, theta is the inverse of the number of firms in the market.

\footnotetext{
${ }^{12}$ The classic on the structure-conduct-performance paradigm is Bain (1956). See Worthington (1990) on the theoretical side and Gilbert (1984) for a critical review of a large number of empirical S-C-P studies up to the early 1980 's. See also Evanoff and Fortier (1988).

${ }^{13}$ This section follows closely the methodology of Shaffer (1999), Genesove and Mullin (1998), Shaffer and DiSalvo (1994), and references cited in these papers. See also Corts (1999).
} 
The method here is to estimate a system of supply and demand functions in order to identify the market power parameter. Thus, the first step is the determination of the demand function to be estimated. A generalized demand function can be written as

$$
Q(P)=\$("-P)^{(}
$$

where $\mathrm{P}$ is the output price, $\$$ is the size of market demand, ( measures the extent of convexity of demand, and " is the maximum willingness to pay. As Genesove and Mullin (1998) point out, this function yields a number of demand functions that can, after definition of the relevant variables, be estimated empirically. In this analysis, I use a linear specification, with the addition of a nonlinear term, as in Shaffer (1999) and Suominen (1994):

$$
Q=a_{0}+a_{1} P+a_{2} G D P+a_{3}\left(P^{*} G D P\right)+,,
$$

where $\mathrm{P}, \mathrm{Q}$, and GDP are, respectively, the price of bank output, the quantity of market output, and gross domestic product-all measured in real terms. The nonlinear term is included to insure the identification of the market power parameter. ${ }^{14}$

The next step is to define a supply condition, based on the marginal cost function. Shaffer (1993, 1999) argues in favor of the translog cost function, because it is flexible in the cost structures it represents and also satisfies the theoretical prediction of linear homogeneity in input prices. Such a function yields a marginal cost relation of the following form:

$$
c_{i}=A C_{i}\left(b_{0}+b_{l} \ln Q_{i}+3_{j} b_{j+1} \ln w_{j i}\right)
$$

such that, $\mathrm{i}$ denotes individual firms, $\mathrm{c}$ is marginal cost, $\mathrm{AC}$ is average cost, $\mathrm{Q}$ is output, and the w's are the prices of inputs to the banking production function (discussed subsequently). Using the demand function (2)

${ }^{14}$ The problem of (and solution for) identification is discussed in Lau (1982) and more briefly in Shaffer (1993). Future work should estimate the other types of demand functions as well. 
to find $P^{\prime}(Q)$, and recalling that $c=P-2 Q P^{\prime}(Q)$, allows the derivation of the following supply condition: $:^{15}$

$$
P_{i}=-2 Q /\left(a_{1}+a_{3} G D P\right)+A C_{i}\left(b_{0}+b_{1} \ln Q_{i}+3_{j} b_{j+1} \ln w_{j i}\right)
$$

The supply and marginal cost conditions bring us to the next problem: defining inputs and outputs in the context of a banking firm. Obviously, in the banking or service sector, such an exercise is more complicated than in the typical manufacturing industry. On this point, a number of other researchers have argued that, clearly, labor and capital are inputs, but that deposits are inputs as well. Thus, input prices are typically computed as the average wage rate (total expenditures on salaries, wages, and benefits divided by the number of employees in the firm), the average price of capital (expenditures on plant and equipment divided by the stock of such items measured at book values), and the average interest rate paid on deposits. ${ }^{16}$ In equation 3 , then, $\mathrm{j}$ will take the values 1 through 3 . In the current cases, it is impossible to calculate exactly some of the input prices, since neither the prices themselves, nor the cost data with which to calculate them, are available. ${ }^{17}$ Ultimately, lack of data excludes capital costs from the analysis, but such inputs are also the least important in the supply function of the bank. Deposit rates are calculated from aggregate and firm-level balance sheet data, while wage rates depend on others' estimates of wages in the banking industry. Average cost is simpler: it is, of course, the ratio of total cost to total earning assets.

Output is another question. ${ }^{18}$ In many studies, output is measured as the value of earning assets, since the primary function of a commercial bank is liquidity or maturity transformation: converting deposits into loans and investments. The issue is more complex in a universal banking system, since much of the business of these institutions revolves around securities underwriting and trading-that is, output that is not fully

\footnotetext{
${ }^{15}$ Implicitly, such a derivation assumes input price taking and profit maximization (cost minimization). It is plausible, however, that neither condition holds in the case of banks with market power. Such a possibility deserves further investigation.

${ }^{16}$ Such definitions are in line with, for example, Mester (1987), Berger et al (1987), and Shaffer (1999), as well as with the model of Klein (1971) and Sealey and Lindley (1977).

${ }^{17}$ The study by Genesove and Mullin (1998) is reassuring about the robustness of estimates of the conduct parameter, theta, to error in cost measurement.

${ }^{18}$ Berger and Humphrey (1992) discuss the problem of measurement in the banking industry. The whole volume in which that article appears, Griliches (1992), is useful in understanding measurement of output in the service sectors.
} 
reflected in the balance sheet. Thus, the measurement of output and revenue should ideally take account of the multi-product nature of the firms. Unfortunately, however, doing so is not possible with the historical data that exist currently. ${ }^{19}$ Nonetheless, if the banks produced a similar division of services over time, then the combined output still follows the movements of the constituent products. To avoid overestimating output prices (by dividing revenues from all areas of service by only the assets reported in the balance sheet), the German output prices are estimated from aggregate average loan rates instead of from accounting data.

Market output is defined as the total value of loans, advances, and discounts of all joint-stock universal banks (in Germany) and of all national banks (in the United States). All figures are deflated by a price index, such that $1913=100$.

The empirical analysis is based on aggregate data for the US and Germany only, since sufficient UK data are as yet unavailable. ${ }^{20}$ The data span the period from 1882 to 1913 (Germany) and 1888 to 1925 (US). Table 4 reports the summary statistics for the two datasets, and an appendix gives detailed definitions and sources. Because of differences in underlying sources and in calculating the variables, it is best not to make too much of the contrasts in the specific variables for the two countries. Yet a few points are worth mentioning. First, average cost of loans (total cost/total loans and discounts) appears to be significantly lower for the German banks than for the American banks. This effect appears despite the fact that German banks's total costs are divided over a smaller share of bank assets (because loans made up a smaller portion of assets in Germany than in the US). Second, in real terms, both loan and deposit rates are at least one percentage point higher in Germany than in the US, but the spread between the two rates is nearly the same (approximately four percent). Similarly, real yields on government bonds are about one percentage point higher in Germany than in the US. Finally, total quantity of loans as a percentage of national income is much higher among the American national banks than among the German universal banks. This ratio reflects the greater proportion of personal financial assets concentrated in the savings banks (and thus, outside the commercial banking sector) in Germany, compared to the US (recall Table 1). ${ }^{21}$

${ }^{19}$ This problem is similar to the one involving cost measurement and is also deserving of further research.

${ }^{20}$ The missing data, costs and profits, are being gathered, but may be unavailable for some time to come.

${ }^{21}$ Obviously, neither series captures the complete commercial loan market, making it difficult to determine just how much bigger those markets were relative to the respective economies. Rough estimates of the German private banking sector would no more than double the given loan estimate, especially later in the period. Since state bank loans would increase the 
Because the analysis here uses aggregate data, and each sample therefore includes at least one complete market, the models yield unbiased estimates of 2 . Using aggregate data also immunizes the test against arbitrary definitions of the local banking market. In this situation, theta represents a weighted average of the firms in the industry, and therefore indicates the level of competitiveness in the economy as a whole. Pricing strategies and market power may vary across markets. Thus, if more than one market is included, 2 is the average degree of market power weighted by market size. If the estimated markup parameter falls near one of the extremes, then it is clear that the predominant mode of competition is near that end of the spectrum. The estimated markup parameter could not be near zero, for example, if the vast majority of markets were not close to competitive. On the other hand, if the parameter falls in the middle, it is more difficult to determine how homogeneous market power is across markets. A mid-range markup parameter can appear either when most or all markets are monopolistically competitive or when some markets are monopolistic but others are competitive. Even with variation among firms and markets, though, time series data will produce unbiased estimates of the average bank's 2 as long as individual firms distribute assets consistently over time.

The quantity and price equations are estimated using both seemingly unrelated regression (SUR) and two-stage least squares (2SLS). In the first procedure, the two equations are jointly estimated, and the coefficients are then used to calculate the conduct parameter, theta. In the second method, the quantity regression is estimated first, and the resulting coefficients are used to construct Q'-the coefficient of which is theta. The two methods are both used in the existing literature, yet in some cases they produce different results for a given sample. Thus, both types of models are presented here.

The bottom row of Table 5 reports the resulting estimates of the markup parameter. In nearly all cases, theta is either zero or even slightly negative. Only in Germany, for the 1882-1913 period, using SUR, does the conduct parameter indicate anything less than perfect competition overall. Even in that case, theta is estimated at 0.14-much closer to perfect competition than to monopoly. In general, in light of the moderate sample sizes, the regression results are relatively strong. Most of the individual parameters are statistically significant, and all of the models are jointly highly significant (all p-values are less than 0.001). Moreover, the explanatory power is high, with almost all adjusted R-squared statistics in the 95 to 99 percent range.

figures for the US, it is clear that the true loan/income ratio is still higher in the US than in Germany. 
The use of annual data does present the possibility of autocorrelation, and Durbin-Watson statistics indicate its presence. Controlling for serial correlation, by using Cochrane-Orcutt and Prais-Winston regression, however, yields nearly identical results for the markup parameter. In particular, all of the estimated thetas remain either indistinguishable from zero or slightly negative. The data also appear to be robust to other changes in specification, such as the use of robust regression, the exclusion of outliers, and varying the time period. Using the Hadi method for identifying multi-variate outliers yields one outlier observation for Germany (1901) but eleven supposed outliers for the US. Given that there are only 38 observations for the US, it seems peculiar to eliminate almost one-third of them as 'outliers.' Thus, we simply analyzed the German data without 1901. The results are nearly unchanged. Likewise, implementing a twostage robust estimator, combining Huber and bi-weight iterations to downweight extreme observations, caused little perturbation of the original findings. All models yield estimates of theta of no more than 0.14-and almost all produce estimates of approximately zero. ${ }^{22}$

The results of the markup test indicate that, on average, competition was thriving in both countries, over an extended period of time, covering markedly different industry structures. Since theta is so low, it also suggests that there was little measurable monopoly power in any substantial individual market or set of markets. Thus, the findings cast doubt on the common idea that universality in itself leads to anti-competitive lending practices. In addition, the results suggest two further conclusions: first, that there is no linear relationship between levels of industry concentration and market power in commercial banking, and second, that the threshold for the appearance of market power in this sector, if it exists, must be high. Both of these hypotheses deserve further corroboration, but given the differences in concentration across the US and between the US and Germany, and the relatively high levels of concentration in certain time periods and submarkets, the similar lack of generalized market power in the two countries is a solid basis for future investigations.

\footnotetext{
${ }^{22}$ Several further model results are reported in an appendix, and still others are available from the author.
} 


\section{Rosse-Panzar method}

In contrast to the markup test, the Rosse-Panzar test for market power uses a reduced-form revenue function to estimate the elasticity of revenues to changes in input prices. ${ }^{23}$ The equation tested here is the following:

$$
\ln T R i=c_{0}+c_{1} \ln T A_{i}+c_{2} \ln M K T+3_{j} c_{j+2} \ln w_{j i}
$$

where $T R$ is real total revenues, $T A$ is real total assets, $M K T$ is the total real market value of deposits, and $w_{j i}$ are the input prices (as defined previously). One might also include measures to control for loan mix or extent of interbank borrowing. The Rosse-Panzar statistic, $H$, is defined as the sum of the elasticities on input prices, or the $3_{j} c_{j+2}$. If the market is characterized either by long-run competitive equilibrium or by perfect contestibility, $H=1$. If the market is monopolistic, the statistic is negative, and if the market is monopolistically competitive, the statistic falls between zero and one. The RP test assumes that the market is in long-term equilibrium, thus most studies also test the accuracy of this assumption by estimating the elasticity of bank returns to changes in input prices (that is, substituting $\ln R O E$ or $\ln R O A$ for $\ln T R$ in equation 5). Negative elasticities of returns suggest disequilibrium, while zero elasticity indicates the opposite.

These tests indicate that the market for commercial banking services was in long-term equilibrium in both the US and Germany in the period investigated here. That is, the sum of input price elasticities of ROA and ROE is non-negative in all cases. This finding is particularly interesting for Germany, given the apparent growth of concentration, especially after the 1890s.

The input price elasticities are mostly insignificantly different from zero, though a number of individual coefficient estimates are negative for both countries. The high variance makes it more difficult to draw strong conclusions about competitiveness, but it is safe to say that there are no elasticity estimates close to one. Moreover, in one cases, the US (1888-1925), the elasticity of wages is very significantly negative and is not offset by the positive elasticity of deposit rates. In addition, in the German case (1882-1913), the negative elasticity estimate for wages is statistically significant at the 11 percent level. While these results suggest some monopoly power in both banking systems, it is important to note that the significance is confined to the

\footnotetext{
${ }^{23}$ See Panzar and Rosse (1987), Shaffer (1982) and Molyneux, et al (1996).
} 
labor inputs-the less important of the two inputs to the commercial loan market, and the variable for which the data are most questionable. Not a single estimate of deposit rate elasticity is significantly negative at any conventional level (p-values on negative coefficients range from 0.7 to 0.94 ), and two estimates are positive.

The Rosse-Panzar results are statistically relatively weak, particularly in comparison with the markup test. While the findings are robust to changes in specification (for example, ROE versus ROA) and use of robust regression, adjustments for serial correlation (Prais-Winston and Cochrane-Orcutt) render the input price elasticities statistically insignificant. Thus, while the R-P test gives some hint of market power, the results are not strong enough to overturn the complete lack of monopoly power found in the previous test. Moreover, to the extent that we believe that some market power exists, it appears equally in the two cases considered here. Thus, the main point-that the conduct of universal and specialized systems is similar-remains intact.

\section{Theoretical Implications}

Hardly anyone adheres any more to the structure-conduct-performance paradigm laid out by Bain (1956), yet many continue to refer to concentration as a proxy for competitiveness. Given that the German and American industries both exhibit close to competitive pricing on average, despite distinct differences in industry structure, it appears that there is no link between concentration and competitiveness.

By appealing to the theoretical literature in industrial organization, the results here may be useful in drawing further inferences about the nature of competition in the banking industry. Given the proliferation of models of industry competition, of course, one can predict nearly any level of competitiveness, depending on the underlying assumptions made. Rather than select a particular model and test how well it fits the results, one may instead work in the opposite direction: the extent of competitiveness, along with the market structure, suggests that certain conditions are in place. In particular, the current findings suggest that banks either compete on price (some form of Bertrand competition), not quantity, or that banking markets are contestable-or both. That is, if banks engaged in Cournot competition with barriers to entry, then competitiveness would be inversely related to industry concentration. As the previous paragraph pointed out, this latter condition appears to be false in the current samples. 
The markup test alone does not distinguish which model-Bertrand competition (with or without contestability) or Cournot competition with contestability-applies to the commercial banking sector. For two reasons, however, it seems likely that the Cournot model cannot accurately describe the commercial banking industry. First, it seems more reasonable that banks compete on prices; they do not appear to fix a price and then adjust quantities. Second, most economists believe that the banking business presents barriers to entry and is therefore imperfectly contestable. This second reason may be weaker than the first, since there was clearly much entry into the commercial banking industry in both the US and Germany in the second half of the nineteenth century. So, barriers to entry, at least during most of the period studied here, were not prohibitive. Still, barriers to entry may have been sufficient to make entry not completely free; particularly in small, thin, or remote markets. And if that were the case, then competition could still be limited in a Cournot world.

The basic Bertrand model, because it suggests that profits are driven to zero with any more than one firm in the market, may overstate the extent of competition in commercial banking. In the Bertrand framework, however, it is simple to produce varying levels of deviation from marginal cost pricing by introducing product differentiation. In the context of banking, one can easily imagine qualitative differences among the population of firms, since access to information, ability to assess risks, and many of the other functions performed by banks depend on individual human abilities. Even without qualitative variations, one only needs transportation costs to yield similar variations in desirability of one firm relative to another. The Salop (1979) circle model seems to fit well with qualitative descriptions of the commercial banking industry, especially in the late nineteenth century when transportation costs were still relatively high and inter-regional markets were imperfectly integrated. Even today, when customers can complete many financial transactions online or by fax and telephone, transportation costs and other means of product differentiation may still prove relevant for certain customers and services.

Knowing the form of competition in the commercial banking sector would help in setting banking policy. If it is true that the banking follows a Bertrand-type model, rather than a Cournot-type model, then it would be clear that regulators could encourage nation-wide branch banking, raising overall concentration in the sector, and not be overly anxious about anti-competitive practices. Entry barriers would also be of less concern than if banks were competing on quantity. Moreover, branching could eliminate local monopolies in rural areas as larger nationwide banks subsume small banks as branches. 


\section{INDUSTRY PROFITABILITY}

In theory, institutional design and scope of services may influence overall bank performance. Differences among banking systems, if significant, should emerge not just in competitiveness, but in long-term rates of return as well. The same common wisdom that views universality as more efficient, but less competitive, than specialization, also implies that universal banking systems should produce higher returns than their specialized counterparts. If universal banks truly gain from economies of scope, then average profitability should be higher in Germany than in either the US or the UK. German banks should also be the most profitable if universal banks exert more monopoly power and therefore earn higher rents than do specialized banks. Finally, German universal banks may earn the highest returns for a third reason: they also provide investment banking services. This higher risk business should produce a higher average return over an extended period.

Given the findings of the previous section, it is doubtful whether the German banks earned monopoly rents on their commercial lending business. Nonetheless, economies of scope and investment banking profits may suffice to raise the German universal banks over the British and American commercial banks. We can test this sixth and final hypothesis by examining two measures of profitability, return on assets (ROA) and return on equity (ROE), for the three countries concerned.

It is, of course, important to temper interpretations for a number of reasons. First, banks may manipulate their reported profits to suit various incentives of their managers. The pressures on banks could run in both directions, so reported profits may exaggerate or understate true profitability. In addition, managers may smooth results from year to year by overstating returns in down years and understating them in up years. In the British case, reporting errors appear to be remarkably large: English and Welsh banks earned much lower and much more variable returns on equity than they announced in their annual statements (Capie, 1988). Second, international disparities in accounting practices and variable construction may lead to apparent deviations among apparent profit rates, even for a given level of underlying profitability. Third, bank employees may erode profits for personal gain (perquisites), particularly in a less-than-perfectlycompetitive industry. These sorts of inefficiencies may vary from country to country. Finally, economic and political conditions that influence bank profitability may vary among the three countries over both the short-run and the long-run. Such economic and political effects may outweigh those stemming from institutional design. 
As these caveats indicate, not all apparent profitability differences are real or based on variation in banking system design and regulation. ${ }^{24}$ Thus, the hypothesis will prove true, and accounting profits will be higher in Germany than in the US and UK, only if returns are indeed greater for universal banks than for specialized banks, and if report manipulations, measurement errors, and differential exogenous influences do not eliminate the premium. ${ }^{25}$

Despite the hypothesized reasons for Germany to evidence higher returns than either the US or the UK, the data in fact show little sustained difference among the three countries (Table 7). Figure 2 plots return on (book value of) equity from 1880 to 1913. German returns grew from less than 8 percent to over 12 percent of equity between 1882 and 1888 , but then declined markedly-with a hiatus in the last half of the 1890s-until the stock market crisis of 1900-01. ROE rebounded until the 1907 stock market crisis and then leveled off until World War I. US returns also declined significantly over the late 1880 s and early 1890 s, but began a generally sustained, and sometimes dramatic, upturn until the same 1907 crisis. UK performance, based on Capie's (1988) figures, follow no perceptible trend, but fluctuate considerably over the period.

Returns on equity diverged significantly in certain years, but overall performance is very similar for the US and Germany. Taking average ROE for the years in which data are available for all three countries, 1888-1913, it is clear that returns are nearly the same for the US (7.4 percent) and Germany (7.7 perc ent), but are significantly lower for the UK (5.8 percent). Not surprisingly, the US-German difference is statistically insignificant, while the UK-German and UK-US differences are highly significant (with well over 99.9 percent confidence). If we ignore Capie's (1988) estimates, however, and only consider reported returns, then the British position is quite the opposite: average ROE exceeds 10 percent and is very significantly different from both US and German ROE. Because similar estimates for the US and Germany do not yet exist, it is difficult to know how to compare Capie's estimated ROE series for the UK with the reported series for the US and Germany. Regardless of which UK figures are used, though, the figures for the other two countries are sufficient to show that ROE is not necessarily higher in the universal system.

Return on assets figures tell a somewhat different story. German universal banks-having held anywhere from 20 to 87 percent more capital and reserves than US commercial banks-depended the most

\footnotetext{
${ }^{24}$ Fohlin (2001, forthcoming) provides extensive comparison of the financial structure of German and British banks.

${ }^{25}$ See the data appendix for further explanations.
} 
heavily on equity. Thus, ROA and ROE are more similar for Germany than for the US. UK banks used even less equity than the Americans, so British ROA would diverge even more from ROE. Unfortunately, ROA figures are currently unavailable for the UK. Returns on assets for the other two countries are more stable and follow a much more noticeable trend than do returns on equity (figure 3). The difference between the two profitability measures is due primarily to the shift in both countries toward greater deposit taking. German universal banks' equity/asset ratio overall fell from 37 to 23 percent between 1888 and 1913, while the US commercial banks' ratio dropped from 31 to 18 percent in the same period. Given this information, as well as the lack of a general upward trend in ROE, it is therefore obvious that ROA must have been declining in both the US and Germany. Figure three also indicates that German ROA was slightly higher than American ROA in most years. For the 1888-1913 period, the German universal banks averaged 2.4 percent ROA, while the American commercial banks averaged 1.7 percent. The mean annual differential was just over threequarters of one percent. Though simple t-tests confirm the very high statistical significance (over 99.9 percent confidence) of the difference in means, the difference could easily stem solely from accounting differences or the averaging in of investment banking returns for the German banks. Moreover, the gap disappears if we eliminate the rather large writeoffs on loans taken by the American banks.

Besides accounting differences, simple comparisons of ROE and ROA obviously ignore what may be major disparities in levels and growth rates of the three economies considered, as well as the prevailing rates of return in other sectors of each economy. For example, Germany and the US were still in the later stages of industrialization during the period studied here, while the UK had begun that process much earlier. One might expect these structural differences to appear in prevailing rates of interest and returns; and clearly, the US and German return figures are more similar to each other than to the UK. One way to account for the contextual variation, is to compute the return on investments in banking in excess of the given country's risk-free rate of return or some other indicator of local costs of finance. Federal government bonds-admittedly an imperfect proxy-is the best proxy available for the risk-free rate. Thus adjusted, ROA and ROE still follow very similar patterns as the original variables, but the levels are markedly different. Adjusted ROE is now significantly higher on average in the US than in Germany, while it is still quite a bit lower overall in England and Wales (figure 4, using Capie's estimates). During the relatively quiet decade of the 1890s, adjusted ROE is actually very close among all three countries, but major divergences are apparent in the years before and after. The large swings are extremely pronounced for the US and Germany, 
and the effects of stock market ups and downs are particularly noticeable for latter. Given that the unadjusted ROA differential between Germany and the US is less than the average spread in interest rates in the two countries, it is not surprising that the US banks produced much higher (or less negative, in this case) adjusted ROA than did German universal banks. Finally, subtracting off loan rates from ROE, yields nearly identical adjusted ROE for the US and Germany on average from 1888 to 1913: 1.51 percent versus 1.58 percent, respectively. Loan-rate adjusted ROE for England and Wales are higher on average than the other two countries (2.33 percent), but the differences fall just short of statistical significance for the period in which all data overlap.

Given the two profitability measures, in their original and adjusted forms, it is clear that this final hypothesis fails. That is, German returns are not significantly and consistently higher than both American and British returns over the period examined. While we can claim a slight absolute ROA advantage for the German universal banks compared to the American banks, in light of the other findings in this section, we cannot attribute the possible premium to superior efficiency. It is likely that we can therefore support an even stronger statement: that universal banks are not significantly more efficient than specialized banks in providing commercial services. Such an hypothesis deserves further attention and a paper of its own.

\section{Conclusions}

This paper makes several related points about the connections among institution design, industry structure, and profitability. First the German universal banking sector was structured quite similarly to the UK commercial banking sector, in that concentration ratios in the two banking industries followed nearly identically upward trends from the early 1880s at least through the early 1920s. In the US, on the other hand, no such pattern emerges overall; and ratios, and their changes over time, vary dramatically by state. These findings therefore provide counterexamples to the widely-held view that universal banking per se leads naturally to greater concentration than does specialized banking.

Second, the German universal banks behaved no less competitively than their American counterparts in the provision of loan services. Structural price markup models, as well as reduced-form Rosse-Panzar tests, demonstrate little deviation from competitive pricing in either country. Additional tests, furthermore, suggest that both markets were in long-term equilibrium, despite the sizeable adjustments in concentration in 
Germany. The findings therefore indicate that universality does not lead to appreciable market power, in either an absolute or a relative sense. These same results also imply that banking industry concentration, at least up to the moderately high levels found in Germany, does not in itself produce anti-competitive behavior. The empirical results, though contradictory to common wisdom about German universal banking, are easily motivated by the theoretical literature in industrial organization.

Third, estimates of returns on equity and on assets suggest only slight international differences in average returns over extended periods, but large deviations in individual years. Adjusting for prevailing rates on government bonds, commercial loans, or commercial deposits narrows the gaps further. German and American rates of return are nearly identical once adjusted, as are spreads between loan and deposit interest rates. British returns are slightly lower, and loan-deposit spreads are significantly lower, than either of the other two countries. Thus, once again, universality is not linked with superior profitability, whether the hypothesized source is efficiency (economies of scope) or monopoly power.

The three sets of results taken together offer important insights for both historical and modern research. From the latter standpoint, the findings may assuage fears that deregulation in American banking could lead to excessive concentration and therefore collusive behavior. At the same time, the results may lower hopes of significant efficiency gains from broadening the scope of services. On the historical side, the results indicate that the traditional accounts over-emphasis at least some of the economic effects of universality during the German industrialization. Finally, this paper hints that the broader economic importance of financial system design may be small when examined over long horizons. Confirming such an hypothesis, of course, hinges on extending the present analysis to other time periods and other countries.

\section{References}

Bain, J. (1956) Barriers to New Competition. Cambridge, MA: Harvard University Press.

Benston, G. J. (1994) “Universal Banking.” Journal of Economic Perspectives 8: 121-143.

Berger, Allen N. and David B. Humphrey (1992) "Measurement and Efficiency in Commercial Banking." In Output Measurement in the Service Sectors (Zvi Griliches, ed.). Chicago: University of Chicago Press, pp. 245-279. 
Berger, Allen N., Gerald A. Hanweck, and David B. Humphrey (1987) "Competitive Viability in Banking: Scale, Scope, and Product Mix Economies.” Journal of Monetary Economics 20: 501-20.

Board of Governors of the Federal Reserve System (1959) All Bank Statistics: United States 1896-1955. Washington D.C.: Library of Congress.

Bodenhorn, Howard. "A More Perfect Union: Regional Interest rates in the United States, 1880-1960," in Michael Bordo and Richard Sylla (eds.), Anglo-American Financial Systems: Institutions and Markets in the Twentieth Century. New York: Irwin.

Brown, Henry P. and Margaret H. Browne (1968) A Century of Pay: the Course of Pay and Production in France, Germany, Sweden, the United Kingdom, and the United States of America, 18601960. New York: St. Martin's Press.

Calomiris, C. (1995) "The Costs of Rejecting Universal Banking: American Finance in the German Mirror, 1870-1914." In N. Lamoreaux and D. Raff (eds.), Coordination and Information: Historical Perspectives on the Organization of Enterprise. Chicago: University of Chicago Press.

Calomiris, Charles (2000) U.S. Bank Deregulation in Historical Perspective. Cambridge: Cambridge University Press.

Capie, Forrest and Alan Webber (1985) A Monetary History of the United Kingdom, 1870-1982. George Allen \& Unwin, Ltd.

Capie, Forrest and Ghila Rodrik-Bali (1982) "Concentration in British Banking 1870-1920." Business History, 24.

Collins, M. (1998) "English Bank Development Within a European Context, 1870-1939.” Economic History Review 51: 1-24.

Corts, K.S. (1999) "Conduct Parameters and the Measurement of Market Power." Journal of Econometrics.

Davis, Lance (1965) “The Investment Market, 1870-1914: The Evolution of a National Market." Journal of Economic History 25.

Dietl, Helmut (1998) Capital Markets and Corporate Governance in Japan, Germany, and the United States: Organizational Response to Market Inefficiencies. New York: Routledge.

Deutsche Bundesbank (1976) Deutsches Geld- und Bankwesen in Zahlen, 1876-1975. Frankfurt: Deutsche Bundesbank.

Donaubauer, Klaus A. (1988) Privatbankiers und Bankenkonzentration in Deutschland von der Mitte des 19. Jahrhunderts bis 1932. Frankfurt am Main: Fritz Knapp Verlag. 
Evanoff, Douglas and Diane Fortier (1988) "Reevaluation of the Structure-Conduct-Performance Paradigm in Banking." Journal of Financial Services Research 1: 277-294.

Fohlin, Caroline (1999a) "Capital Mobilisation and Utilisation in Latecomer Economies: Germany and Italy Compared." European Review of Economic History 2: 139-174.

Fohlin, Caroline (1999b) “Universal Banking in Pre-World War I Germany: Model or Myth?” Explorations in Economic History 36: 305-343.

Fohlin, Caroline (2000) "Economic, Political, and Legal Factors in the Development of Financial Systems: International Patterns in Historic al Perspective," Social Science Working Paper No. 1089, California Institute of Technology.

Fohlin, Caroline (2001) "The Balancing Act of German Universal Banks and English Deposit Banks, 18801913." Business History (forthcoming).

Friedman, Milton and Anna Schwartz (1982) Monetary Trends in the United States and the United Kingdom. Chicago: University of Chicago Press.

Gendreau, Brian C. (1999) "Risk Structure of Postbellum U.S. Deposit Rates." Explorations in Economic History. Vol. 36. pg. 409-427.

Genesove, David and Wallace P. Mullin (1998) "Testing Static Oligopoly Models: Conduct and Cost in the Sugar Industry, 1890-1914.” RAND Journal of Economics 29, (2): 355-377.

Gilbert, R. Alton (1984) "Bank Market Structure and Competition: A Survey." Journal of Money, Credit, and Banking 16 (4): 617-45.

Goodhart, C.A.E. (1972) The Business of Banking, 1891-1914. London: Weidenfeld \& Nicolson.

Goldsmith, Raymond W. (1969) Financial Structure and Development. New Haven: Yale University Press.

Griliches, Zvi, ed. (1992) Output Measurement in the Service Sectors. Chicago: University of Chicago Press.

Handbuch der Deutschen Aktiengesellschaaften, various years.

Hoffman, Walther (1965) Das Wachstum der Deutschen Wirtschaft seit der Mitte des 19. Jahrhunderts New York: Springer-Verlag.

Homer, Sidney and Richard Sylla (1991) A History of Interest Rates. 3rd Ed. New Brunswick: Rutgers University Press.

James, John (1978) Money and Capital Markets in Postbellum America. Princeton University Press. Princeton, New Jersey. 
Klein, Michael (1971) "A Theory of the Banking Firm.” Journal of Money, Credit, and Banking 7: 20518.

Lau, Lawrence (1982) "On Identifying the Degree of Competitiveness from Industry Price and Output Data." Economics Letters 10: 93-99.

Maddison, Angus (1995) Monitoring the World Economy 1820-1992. Paris: Organisation for Economic Co-Operation and Development.

Mester, Loretta J. (1987) “A Multiproduct Cost Study of Savings and Loans." The Journal of Finance 42: 423-45.

Molyneux, Philip, John Thornton, and D. Michael Lloyd-Williams (1996) "Competition and Market Contestability in Japanese Commercial Banking." Journal of Economics and Business 48:33-45.

Panzar, John C. and James N. Rosse (1987) "Testing for 'Monopoly' Equilibrium." The Journal of Industrial Economics 35: 443-456.

Pohl, Manfred (1982) Konzentration im deutschen Bankwesen, 1848-1980. Frankfurt, Germany.

Rajan, Raghuram G. and Luigi Zingales (1999) “The Politics of Financial Development." Mimeo, The University of Chicago.

Riesser, Jacob (1910) Die deutschen Großbanken und ihre Konzentration, Jena: Verlag von Gustav Fischer. [English translation: The German Great Banks and their Concentration. Published by The National Monetary Commission (Washington: Government Printing Office), 1911.]

Saling's Börsen-Jahrbuch (various years).

Salop, Steven (1979) "Monopolistic Competition with Outside Goods," Bell Journal of Economics 10: 14156.

Sealey, Calvin W., Jr. and James T. Lindley (1977) "Inputs, Outputs, and a Theory of Production and Cost at Depository Financial Institutions." Journal of Finance 32: 1251-66.

Shaffer, Sherrill (1982) “A Nonstructural Test for Competition in Financial Markets." Proceedings of the 17th Conference on Bank Structure and Competition [Chicago Fed], pp. 225-43.

Shaffer, Sherrill (1993) "A Test of Competition in Canadian Banking." Journal of Money, Credit, and Banking 25 (1): 49-61.

Shaffer, Sherrill (1999) "Ownership Structure and Market Conduct Among Swiss Banks." Mimeo, University of Wyoming.

Shaffer, Sherrill and James DiSalvo (1994) "Conduct in a Banking Duopoly." Journal of Banking \& Finance 18: 1063-1082. 
Shepard, D.K. (1971) The Growth and Role of UK Financial Institutions, 1880-1962. London: Methuen.

Suominen, Matti (1994) "Measuring Competition in Banking: A Two-Product Model." Scandinavian Journal of Economics 96 (1): 95-110.

Sylla, Richard (1966) "Federal Policy, Banking Market Structure, and Capital Mobilization in the United States, 1863-1913." The Journal of Economic History 29 (4): 657-86.

U.S. Bureau of the Census (1960) Historical Statistics of the United States, Colonial Times to 1957. Washington D.C.: U.S. Government Printing Office.

U.S. Comptroller of the Currency (various years) Annual Report.

Weber, A. (1915) Depositenbanken und Spekulationsbanken: Ein Vergleich deutschen und englischen Bankwesens. München und Leipzig: Verlag von Duncker \& Humboldt.

Whale, P. Barrett (1930) Joint-Stock Banking in Germany. London: MacMillan and Co.

Worthington, Paula R. (1990) “Strategic Investment and Conjectural Variations." International Journal of Industrial Organization 8: 315-28. 


\section{Appendix A: Data Sources and Variable Definitions}

The markup model uses 8 variables: Quantity of output, or total loans $(\mathrm{Q})$, total cost $(\mathrm{C})$, some measure of national income $(\mathrm{Y})$, price of output, or loan rate $(\mathrm{P})$, price of a substitutes $(\mathrm{Z})$, price of capital inputs, or deposit rates (W1), and price of labor inputs, or average annual income of an employee in the banking industry (W2). Appropriate aggregated bank statistics were obtained or estimated for the United States and Germany, for all years feasible between 1880 and 1925. Most data for the US begins only in 1888, and several important series for Germany are missing observations for 1914-1919.

United States: 1888-1925

For the Total Loans (Q) and Aggregated Expenses (C), in millions of US dollars, for all U.S. National banks, statistics were obtained from the Historical Statistics of the United States and by private communication with Howard Bodenhorn. These data will be soon published in the updated Historical Statistics.

National income comes from Friedman and Schwartz (1982), reported in billions of US dollars.

A number of sources estimate average loan rates of National Banks. The Annual Report of the Comptroller of the Currency also provides reported loan rates from surveys of all National banks for the years 1889, 1894, and 1899. Brian Gendreau (1999) reports these loan rates, averaged by region, for the East, Midwest, South, and West. Bodenhorn (2000) estimates loan rates by four slightly different geographic regions (Northeast, South, Plains, West) for 1880 to 1960. Finally, John James (1978) estimates regional interest rates from 1888 to 1911 . His source of information is Bradstreet's, a weekly trade journal.

James (1978) and Bodenhorn (2000) use two different methods in calculating loan rates. The James equation for the "average rate of return on the loan and discount portfolio" is the following:

$$
\text { (Eq. 1) } R_{t}=\left(G E_{t}-r U S\left(B C_{t}+B D_{t}\right)-r B B * D B_{t}-r R R B * O S B_{t}\right) /\left(L D_{t-1}-L_{O S S E S}\right) \text {, }
$$

where GE is gross earnings; rUS is the average interest rate on government bonds; $\mathrm{BC}$ is bonds for circulation; $\mathrm{BD}$ is bonds for deposit; rBB is the interest rate on bankers' balances; DB is Due from Banks; rRRB is the interest rate on prime railroad bonds, OSB is other stocks and bonds, LD is loans and discounts; and LOSSES is the loss suffered by banks for that year.

Bodenhorn adjusted this equation as follows:

$$
\text { (Eq. 2) } I_{t}=\left(G E_{t}-r U S *(U S)-r O T H E R * O B_{t}-r C B * C B_{t}\right) /\left(L D_{t-1}+O D_{t}-L S R_{t}\right) \text {, }
$$

where GE is gross earnings; rUS is the rate on U.S. securities; US is United States securities; rOTHER is the rate on other government and corporate bonds; $\mathrm{OB}$ is other bonds; $\mathrm{rCB}$ was the rate paid on correspondent balances; CB is correspondent balances; LD is loans and discounts; OD is overdrafts; and LSR is loan losses or defaults.

The estimates for the current paper derive from Bodenhorn's method and make use of aggregate bank data in Historical Statistics. For the rate paid on "correspondent balances," rCB, in line with both Bodenhorn and 
James, we assume the rate to be constant at 2 percent per annum. (See Bodenhorn (2000, pg. 448). He points to John James for his rationale.)

Since the amount of securities of states \& political subdivisions and the amount of other securities held by the banks were reported separately, two separate bond rates for government bonds and corporate bonds, as opposed to Bodenhorn's single rate $\mathrm{r} 1$ for both, could be used in a modified estimate of loan rates. Hence, rates of interest for U.S. securities, rUS, other, or state and city, bonds, r1, and on corporate bonds, $r 2$ needed to be estimated.

For rUS, we use a simple, unweighted average of all government bonds reported in Homer and Sylla (1991) for each year. For example, the rates for the US Refunding 4.5s of 1891 and the rates for the US Refunding 4s of 1907 were added up for each year from 1880-1891 and divided by two to obtain an average.

Municipal bond rates ( r1) come from Homer and Sylla, tables 42, 43, 45, 46, 47, and 48. Corporate bond rates, r2, are the railroad bond rate for 1880-1900 and the prime corporate rate for 1900-1926, both reported by Homer and Sylla.

However, it was necessary to extrapolate back from 1888-1896 for the weights to make a weighted average for the loan rates for 1888-1895. We know that Banker's Balances (1896-1925) + Cash Items in Collection $(1896-1925)=$ Due from Banks (1888-1925), with the years for which each item is reported explicitly in parentheses. Due from Banks is reported in the years we seek to estimate, 1888-1896, allowing us to estimate the other two items. We obtain a parameter, 1, by setting

\section{(Eq. 3) Banker's Balances $/($ Bankers' Balances + Cash in Collection $)=l$}

Then by multiplying Due from Banks (1888-1925) by the 1 factor, we obtain an estimate of Bankers' Balances for 1888-1896: Bankers' Balances1888-1896 $=1 *$ Due from Banks1888-1896. A linear regression line was determined ( 1 was $1=0.0038$ (year) +0.8211$)$ and used to extrapolate for Bankers' Balances for 1888-1896.

Similarly, a weighted average interest rate for U.S. Government securities, Securities of states \& political subdivisions, and Other securities, was needed for 1888 to 1896, since these items were not reported in Historical Statistics or by Bodenhorn, for those years. A linear regression was conducted on time series data for U.S. Government securities, Securities of states \& political subdivisions, and other securities, each divided by Total investments. This yielded another 1 factor, similar to the one calculated above for estimating Bankers' Balances. The total amount of investments for the years 1888-1896 were reported explicitly, so by multiplying the linear function, extrapolated back to 1888 , by the total investments for each year, weighted average interest rates for U.S. Government Securities, Securities of States \& Political Subdivisions, and Other Securities were obtained for 1888 to 1896.

Following previous studies, the price of a substitute product, Z, is taken to be the rate of U.S. Government bonds. These prices are compiled from figures given in Homer and Sylla (1991), noted previously. This estimated rate of issued government bonds (Z3) was used in estimating loan rates of all National banks, as well as estimating Y. Two additional measures of $\mathrm{Z}$, the commercial paper rate and the yield on high-grade corporate bonds, come from Friedman and Schwartz (1982). 
Deposit rates (W1) also had to be estimated. The equation to estimate deposit rates is defined as follows:

$$
\text { (Eq.4) } W 1=\left[\text { Expenses }_{t}+(\text { net losses }(-), \text { net recoveries }(+))_{t}\right] / \text { Total Deposits } s_{t}
$$

National Bank data for expenses, net losses, and total deposits, from 1869 to 1991, come from Historical Statistics (and from Bodenhorn). The Annual Report of the Comptroller of the Currency and Gendreau (1999) report deposit rates of U.S. National banks for intermittent years from 1897 to 1913. Our estimated rates compare closely to these reported rates in the given years.

Annual wages in banking, W2, come from Historical Statistics; it reports the 'average annual earnings per full time employee in finance, insurance, and real estate' calculated by Stanley Lebergott for the years from 1900 to 1970. Estimates of W2 for 1888 to 1899, derive from average annual money wages for the US, 1860 to 1913, reported by Brown and Browne (1968). For 1900 to 1913, a ratio of the average annual wage of a Finance, Insurance, or Real Estate employee to the average annual wage of any employee was determined. This ratio was determined to be constant (and equal to 2.27) for this range of years. Thus, W2 is estimated by multiplying this ratio by the Brown and Browne wage series for 1888 to 1899 .

Friedman and Schwartz (1982) report an Implicit Price Deflator $(1929=100)$, for 1869 to 1925 . The corresponding Implicit Price Deflator, normalizing for $1913=100$. The inflation rate is calculated from this Implicit Price Deflator $(1913=100)$. Real values of percent variables are then computed as the difference between nominal rates and the inflation rate, and real values of level variables are calculated as (nominal values/deflator)*100.

Germany: 1880-1913

For Q, Deutsche Bundesbank (1976) reports total loans for all joint-stock credit banks for 1883 to 1920. Also, the United States National Monetary Commission reported Total Loans (in millions of Marks) from 1870 to 1906, but had included a smaller number of banks. Hence, to obtain estimates of loans before 1883, we fitted a second-order polynomial regression for All Bank Loans (Deutsche Bundesbank) vs. Loans (National Monetary Commission). We then extrapolate for All Bank Loans for 1870 to 1882.

For C, Saling's Börsen Jahrbuch reports various expenses for all banks listed on the Berlin Stock Exchange. We summed reported expenses for each credit bank and then aggregated the expenses of all banks for each year, from 1882 to 1901 . For each year, we then calculated a ratio of Total Cost of all Credit banks to Total Assets of all Credit banks (gathered from the same source). Total Assets inferred from Saling's Borsen Papier differ in value from the Total Assets reported by Deutsches Geld- und Bankwesen in Zahlen 1876-1975 by a negligible amount. However, the Total Assets reported by Deutsches Geld- und Bankwesen in Zahlen 1876-1975 included small banks that are not reported in the Berlin Stock Exchange, as with Saling's sample. So with a ratio of Total Cost to Total Assets from Saling's Borsen Papier for each year, Total Assets from Deutsches Geld- und Bankwesen in Zahlen 1876-1975 could be multiplied by the ratio and an aggregate Total Cost for all banks could be estimated.

For the years 1896-1899 and 1902-1912, a sample of all joint-stock credit banks was taken from the Handbuch der deutschen Aktiengesellschaften and the above method produced corresponding estimates 
of total costs for these years (the years for which the HDAG is available). Despite the differences in coverage of the two sources, the two cost series are very similar for overlapping years.

National income, Y, is calculated as net national product (NNP), as reported in Hoffmann (1965).

For Z, we use a simple average for German government bond yields reported in Homer and Sylla for 1870 to 1921. We use all reported bonds, such as Prussian State 3 1/2s, Prussian State 4s, Bavarian 4s, bonds, for each year. Rates computed from Hoffman's reports of total volume of government bonds and amounts paid thereon are similar.

The loan rate, $\mathrm{P}$, is estimated from the relationship between the rate on current accounts and the Lombard rate from 1924 to 1944, when the current account rate was first reported. To obtain data for the target 1880 to 1913 years, we regressed the current account rate on the Lombard rate for 1924 to 1944. The regression gives a strong linear fit with a coefficient of 1.14 and a constant of 0.87 . Since the slope coefficient was statistically equal to 1 , we estimated loan rates prior to the year 1924 as a constant $(0.87)$ premium over the Lombard rate.

For W1, Motschmann (1915) reports interest rates on deposits for various dates within each year for 1892 to 1913. Thus, a weighted average for interest on deposits at the Deutsche Bank was calculated for each year, by enumerating the number of days between each reporting of the interest rate, and then weighting the average based upon those number of days that a depost rate was effective for.

For the deposit rate before 1892, we used the expenses taken from Saling's. Saling's reports, for a subset of banks, Interest on Deposits (sometimes differentiating between current accounts and demand deposits) and Deposits (and Current Accounts). Hence, average deposit rates could be estimated by determining the ratio, for all reporting credit banks, of the sum of interest paid on deposits to the sum of deposits or deposits and current accounts. For years overlapping with the Motschmann data, the rates were remarkably close (within a two or three tenths of a percent).

Total revenues for all banks was determined from Saling's and HDAG in a manner similar to Total Costs to Total Assets. Total revenues, summed for all credit banks, was divided by Total Assets, summed from all credit banks, for each year. Knowing this ratio and multiplying each year by the Total Assets of all Banks reported in Deutsche Bundesbank (1976), we obtain an appropriate estimate for Total Revenues. ROA and ROE are then computed from these figures and total assets and total equity (capital plus reserves) from Deutsche Bundesbank (1976).

W2 comes from Hoffman's (1965) series of average annual income for an employee in the service sector (Handel, Banken, Versicherungen, Gaststätten).

The GNP deflator $(1913=100)$ derives from the deflator $(1890-99=100)$ calculated in Brown and Browne (1968). The inflation rate is also calculated from this GNP deflator

Total Deposits (deposits and current accounts) for all joint-stock universal banks comes from Deutsche Bundesbank (1976). 
Table 1. The Financial Systems of Germany, the United States, and the United Kingdom

ca. 1880

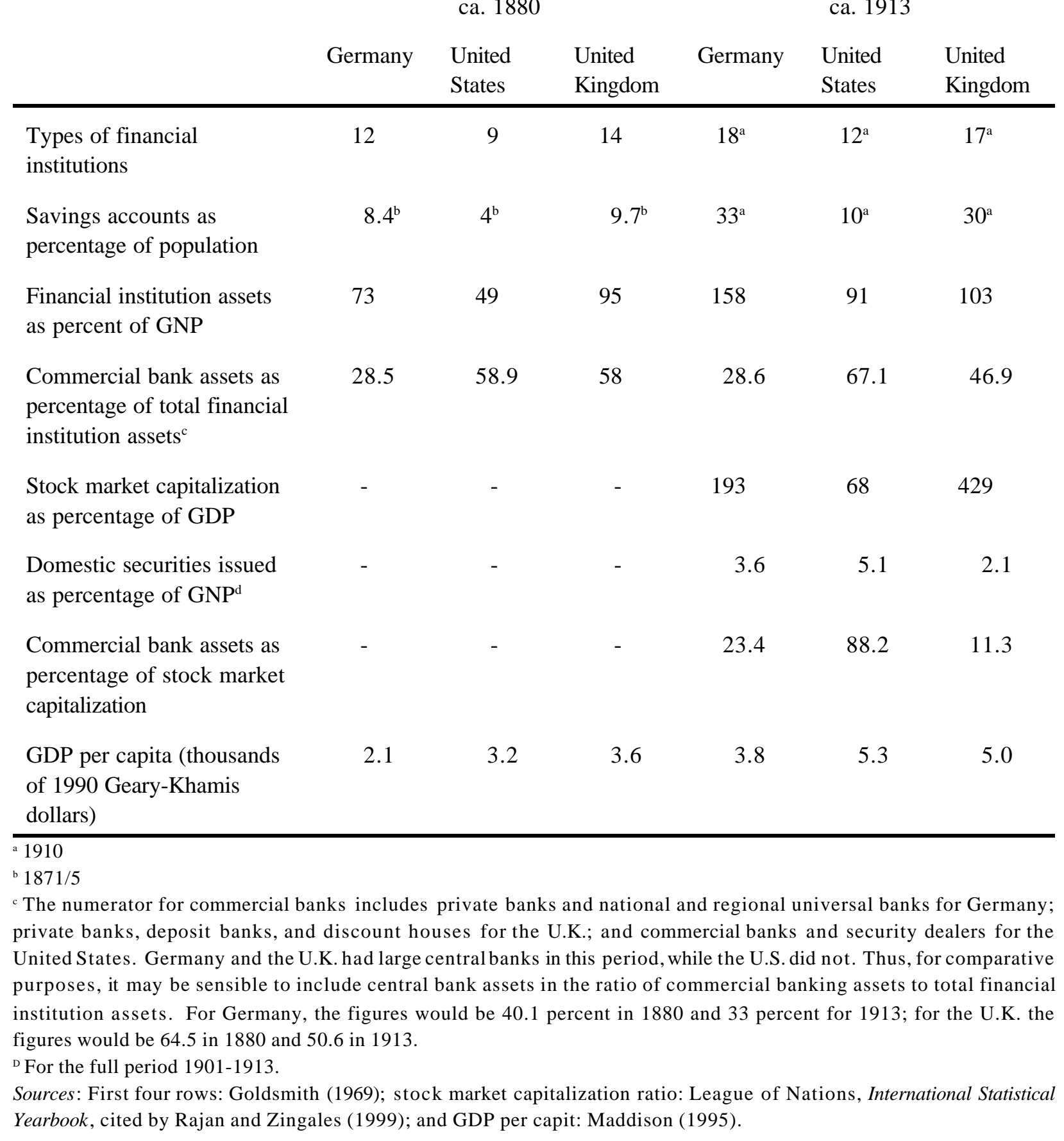


Table 2. Banking Industry Structure

\begin{tabular}{|c|c|c|c|c|c|c|c|c|c|}
\hline & \multicolumn{3}{|c|}{1890} & \multicolumn{3}{|c|}{1900} & \multicolumn{3}{|c|}{1910} \\
\hline & Germany & U.S. & U.K. & Germany & U.S. & U.K. & Germany & U.S. & U.K. \\
\hline $\begin{array}{l}\text { Thousands of } \\
\text { people/bank }{ }^{\mathrm{a}}\end{array}$ & 302 & 6.3 & 115.5 & 268 & 6.1 & 204.4 & 221 & 3.8 & 374.4 \\
\hline $\begin{array}{l}\text { Thousands of } \\
\text { people/banking office }\end{array}$ & 211 & 6.3 & 7.5 & 45.1 & 6.1 & 6.3 & 14.8 & 3.7 & 5.5 \\
\hline Branches per bank ${ }^{\mathrm{b}}$ & $\begin{array}{r}0.98 \\
(2.6)\end{array}$ & 0 & 14.3 & $\begin{array}{r}1.01 \\
(4.4)\end{array}$ & $\begin{array}{l}0.01 \\
(1.4)\end{array}$ & 31.5 & $\begin{array}{c}4.3 \\
(16.8)\end{array}$ & $\begin{array}{r}0.02 \\
(1.9)\end{array}$ & 67.5 \\
\hline $\begin{array}{l}\text { Average assets/bank } \\
\text { (millions } 1913 \text { dollars) }\end{array}$ & 9.4 & 0.64 & 27.8 & 15.6 & 0.89 & 43.3 & 23.3 & 0.79 & 73.7 \\
\hline $\begin{array}{l}\text { Five-firm } \\
\text { concentration ratio }^{c}\end{array}$ & $\begin{array}{l}19 \\
(37.1)\end{array}$ & 3.2 & $\begin{array}{l}21 \\
(26.5)\end{array}$ & $\begin{array}{c}22.5 \\
(33.8)\end{array}$ & 6.5 & $\begin{array}{l}25.5 \\
(31)\end{array}$ & $\begin{array}{c}29.3 \\
(36.9)\end{array}$ & 6.23 & $\begin{array}{l}35.5 \\
(43)\end{array}$ \\
\hline $\begin{array}{l}\text { Ten-firm } \\
\text { concentration ratio }^{c}\end{array}$ & $\begin{array}{c}28.8 \\
(56.3)\end{array}$ & 5.6 & $\begin{array}{l}32 \\
(38)\end{array}$ & $\begin{array}{l}33.3 \\
(50)\end{array}$ & 9.8 & $\begin{array}{l}41 \\
(46.3)\end{array}$ & $\begin{array}{c}43.5 \\
(54.8)\end{array}$ & 9.06 & $\begin{array}{l}56 \\
(64.7)\end{array}$ \\
\hline
\end{tabular}

Notes:

${ }^{a}$ Population per branch includes the main office. Number of banks and branches for the UK comes from Capie and Webber(1985). For Germany, 1890 figures are estimated based on joint-stock banks listed in Berlin (reported in Saling's, 1891); thus, population perbranch and branches perbank are overestimated. Number of banks for Germany comes from Deutsche Bundesbank (1976), but those numbers are lower than the number of banks reported in the Handbuch der deutschen Aktiengesellschaften (HDAG) under credit banks. Branches perbank and population per branch for Germany in 1900 and 1910 come from HDAG. So, for Germany, people per bank and people per branch are not comparable. See discussion in text.

${ }^{b}$ Branches per bank excludes the main office. For the U.S. and Germany, figures in parentheses are the number of branches per bank that owned branches (not including the main office itself).

${ }^{c}$ Figures in parentheses, for Germany, exclude estimated private bank assets; and, for the U.K., include only England and Wales. Available series exclude private banks for Germany. The concentration ratios estimated for the U.K. by Capie and Rodrik-Bali include private banks. The ratios for the US are from 1908. Ratios for 1913 are 4.45 and 6.78 . See discussion in text. 
Table 3. Concentration Ratios by State

\begin{tabular}{|c|c|c|c|c|}
\hline State & Top 5 b & ion rat & $\mathrm{ks}(\mathrm{Na}$ & \\
\hline Year & 1890 & 1000 & 1008 & 1013 \\
\hline Alabama & & 24.89 & 22.42 & 21.23 \\
\hline Alaska & & 16.26 & 9.84 & 30.72 \\
\hline Arizona & & 42.68 & 30.23 & 22.13 \\
\hline Arkansas & & 21.21 & 13.53 & 11.71 \\
\hline California & 11.85 & 10.34 & 13.50 & 15.91 \\
\hline Colorado & 32.52 & 58.77 & 41.94 & 35.87 \\
\hline Connecticut & & 17.82 & 14.46 & 14.31 \\
\hline Delaware & & 36.40 & 29.47 & 21.36 \\
\hline District of Columbia & & 39.04 & 37.16 & 22.35 \\
\hline Florida & & 43.19 & 32.77 & 25.52 \\
\hline Georgia & & 16.52 & 17.84 & 13.74 \\
\hline Hawaii & & & 16.26 & 14.89 \\
\hline Idaho & & 47.34 & 20.33 & 20.52 \\
\hline Illinois & 86.47 & 25.70 & 25.42 & 25.78 \\
\hline Indiana & & 16.95 & 13.70 & 12.86 \\
\hline Iowa & & 4.80 & 5.25 & 5.37 \\
\hline Kansas & & 14.75 & 12.56 & 7.88 \\
\hline Kentucky & & 19.13 & 15.80 & 15.08 \\
\hline Louisiana & & 41.46 & 26.03 & 25.80 \\
\hline Maine & & 22.65 & 19.21 & 18.80 \\
\hline Maryland & & 24.31 & 23.56 & 23.06 \\
\hline Massechusetts & & 17.74 & 30.26 & 28.59 \\
\hline Michigan & 35.29 & 11.81 & 12.85 & 14.77 \\
\hline Minnesota & & 22.53 & 33.47 & 28.25 \\
\hline Mississippi & & 14.64 & 10.40 & 10.44 \\
\hline Missouri & 40.10 & 31.61 & 29.96 & 24.76 \\
\hline Montana & & 26.58 & 21.39 & 15.94 \\
\hline Nebraska & & 27.47 & 24.12 & 20.21 \\
\hline Nevada & & 13.84 & 32.95 & 38.69 \\
\hline New Hampshire & & 19.73 & 18.79 & 20.14 \\
\hline New Jersey & & 13.35 & 12.40 & 9.93 \\
\hline New Mexico & & 59.44 & 36.53 & 32.77 \\
\hline New York & 40.67 & 18.17 & 25.16 & 18.35 \\
\hline North Carolina & & 19.98 & 14.41 & 10.23 \\
\hline North Dakota & & 18.11 & 12.84 & 8.08 \\
\hline Ohio & & 14.36 & 14.42 & 12.70 \\
\hline Okalahoma & & 17.32 & 13.58 & 13.54 \\
\hline Oregon & & 29.99 & 27.10 & 26.30 \\
\hline Pennesylvania & & 10.42 & 11.88 & 10.24 \\
\hline Rhode Island & 29.21 & 16.55 & 15.96 & 17.55 \\
\hline South Carolina & 49.69 & 16.61 & 18.96 & 15.40 \\
\hline South Dakota & & 15.75 & 9.90 & 6.96 \\
\hline Texas & 10.95 & 10.61 & 10.09 & 11.59 \\
\hline Tennessee & & 22.10 & 19.14 & 20.07 \\
\hline Utah & & 27.69 & 29.51 & 27.48 \\
\hline Vermont & 22.83 & 19.03 & 14.32 & 12.26 \\
\hline Virginia & 28.26 & 22.15 & 19.19 & 20.72 \\
\hline Washington & & 26.93 & 25.76 & 22.12 \\
\hline West Virginia & & 15.11 & 11.24 & 10.45 \\
\hline Wisconsin & & 30.35 & 20.17 & 16.78 \\
\hline
\end{tabular}


Table 4. Summary Statistics

\begin{tabular}{|c|c|c|c|c|}
\hline Variables & $\begin{array}{l}\text { Germany } \\
1882-1913\end{array}$ & $\begin{array}{l}\text { Germany } \\
1892-1913\end{array}$ & $\begin{array}{c}\text { US } \\
1888-1925\end{array}$ & $\begin{array}{c}\text { US } \\
1892-1913\end{array}$ \\
\hline Q & 4636.43 & 5939.35 & 4780.26 & 4137.58 \\
\hline Total amount of loans (mil. 1913 marks) & 2990.10 & 2732.48 & 1801.55 & 1236.79 \\
\hline TD & 3895.44 & 5095.03 & 6410.14 & 5416.57 \\
\hline Total deposits & 2974.78 & 2866.29 & 2868.76 & 1903.46 \\
\hline $\mathrm{C}$ & 100.67 & 127.01 & 208.53 & 135.10 \\
\hline $\begin{array}{l}\text { Total cost-total interest and non-interest } \\
\text { expenses (mil. } 1913 \text { marks) }\end{array}$ & 63.33 & 59.88 & 145.05 & 64.53 \\
\hline $\mathrm{AC}$ & 0.02 & 0.02 & 0.04 & 0.03 \\
\hline Average cost (C/Q) & 0.005 & 0.005 & 0.01 & 0.01 \\
\hline $\mathrm{Y}$ & 104952.37 & 117149.47 & 27511.64 & 23484.47 \\
\hline National Income/Product (mil. 1913 marks) & 22158.96 & 14751.42 & 10267.48 & 6001.86 \\
\hline $\mathrm{Q} / \mathrm{Y}$ & 4.06 & 4.87 & 17.30 & 17.45 \\
\hline Total amount of loans/income (percent) & 1.90 & 1.74 & 1.40 & 1.08 \\
\hline $\mathrm{Z}$ & 2.98 & 2.95 & 0.58 & 1.23 \\
\hline Interest rate on government bonds & 2.19 & 2.31 & 6.55 & 3.13 \\
\hline $\mathrm{Z1}$ & & & 2.75 & 3.61 \\
\hline Commercial paper rate & & & 6.27 & 2.69 \\
\hline $\mathrm{Z} 2$ & & & 1.90 & 2.59 \\
\hline Yield on high-grade corporate bonds & & & 6.28 & 2.93 \\
\hline $\mathrm{P}$ & 5.34 & 5.48 & 4.09 & 4.70 \\
\hline Loan rate & 2.20 & 2.29 & 6.41 & 2.93 \\
\hline W1 & 1.36 & 1.52 & 0.29 & 0.67 \\
\hline Deposit rate & 2.15 & 2.22 & 6.13 & 2.83 \\
\hline W2 & 956.33 & 1005.18 & 1227.09 & 1293.03 \\
\hline Annual wage (1913 marks/dollars) & 89.84 & 61.73 & 130.41 & 62.45 \\
\hline
\end{tabular}

Note: Standard deviation recorded in italics below mean; all variables are in real (1913) values. Q, TD, C, and $\mathrm{Y}$ are in millions of dollars for U.S. and millions of marks for Germany. Divide 1913 marks by 5 to obtain approximate value in 1913 dollars. 
Table 5. Estimation of Markup Models, United States and Germany

\begin{tabular}{|c|c|c|c|c|c|c|c|c|}
\hline \multirow[t]{2}{*}{ Variable } & \multicolumn{2}{|c|}{ Germany, 1882-1913 } & \multicolumn{2}{|c|}{ Germany, 1892-1913 } & \multicolumn{2}{|c|}{ US, 1888-1913 } & \multicolumn{2}{|c|}{ US, 1888-1925 } \\
\hline & SUR & 2SLS & SUR & 2SLS & SUR & $2 \mathrm{SLS}$ & SUR & 2SLS \\
\hline $\mathrm{P}$ & $\begin{array}{r}-1542.40 \\
0.31\end{array}$ & $\begin{array}{r}-2414.68 \\
0.21\end{array}$ & $\begin{array}{r}-1938.61 \\
0.22\end{array}$ & $\begin{array}{r}-2308.42 \\
0.27\end{array}$ & $\begin{array}{r}420.95 \\
0.13\end{array}$ & $\begin{array}{r}372.39 \\
0.27\end{array}$ & $\begin{array}{r}-513.94 \\
0.06\end{array}$ & $\begin{array}{r}-509.42 \\
0.11\end{array}$ \\
\hline Y & $\begin{array}{l}0.09 \\
0.003\end{array}$ & $\begin{array}{l}0.83 \\
0.03\end{array}$ & $\begin{array}{l}0.18 \\
0.00\end{array}$ & $\begin{array}{l}0.19 \\
0.001\end{array}$ & $\begin{array}{r}293.72 \\
0.00\end{array}$ & $\begin{array}{r}281.44 \\
0.001\end{array}$ & $\begin{array}{r}73.36 \\
0.03\end{array}$ & $\begin{array}{r}74.16 \\
0.06\end{array}$ \\
\hline $\mathrm{Z}$ & $\begin{array}{r}1863.94 \\
0.25\end{array}$ & $\begin{array}{r}3166.52 \\
0.12\end{array}$ & $\begin{array}{r}3420.66 \\
0.04\end{array}$ & $\begin{array}{r}4123.88 \\
0.07\end{array}$ & $\begin{array}{r}-457.54 \\
0.14\end{array}$ & $\begin{array}{r}-376.59 \\
0.32\end{array}$ & $\begin{array}{r}423.97 \\
0.10\end{array}$ & $\begin{array}{r}445.93 \\
0.13\end{array}$ \\
\hline $\mathrm{P}^{*} \mathrm{Y}$ & $\begin{array}{l}0.02 \\
0.18\end{array}$ & $\begin{array}{l}0.03 \\
0.13\end{array}$ & $\begin{array}{l}0.02 \\
0.17\end{array}$ & $\begin{array}{l}0.02 \\
0.24\end{array}$ & $\begin{array}{r}-22.91 \\
0.14\end{array}$ & $\begin{array}{r}-19.24 \\
0.30\end{array}$ & $\begin{array}{l}26.68 \\
0.004\end{array}$ & $\begin{array}{r}27.26 \\
0.01\end{array}$ \\
\hline $\mathrm{P} * \mathrm{Z}$ & $\begin{array}{r}-16.13 \\
0.55\end{array}$ & $\begin{array}{r}-22.12 \\
0.52\end{array}$ & $\begin{array}{r}-15.24 \\
0.47\end{array}$ & $\begin{array}{r}-6.14 \\
0.82\end{array}$ & $\begin{array}{l}2.66 \\
0.55\end{array}$ & $\begin{array}{l}1.77 \\
0.74\end{array}$ & $\begin{array}{l}1.90 \\
0.01\end{array}$ & $\begin{array}{l}1.71 \\
0.05\end{array}$ \\
\hline $\mathrm{Y}^{*} \mathrm{Z}$ & $\begin{array}{r}-0.02 \\
0.17\end{array}$ & $\begin{array}{r}-0.03 \\
0.09\end{array}$ & $\begin{array}{r}-0.03 \\
0.03\end{array}$ & $\begin{array}{r}-0.04 \\
0.06\end{array}$ & $\begin{array}{r}25.86 \\
0.12\end{array}$ & $\begin{array}{r}20.95 \\
0.30\end{array}$ & $\begin{array}{r}-23.56 \\
0.01\end{array}$ & $\begin{array}{r}-24.84 \\
0.02\end{array}$ \\
\hline Constant & $\begin{array}{r}-5170.21 \\
0.12\end{array}$ & $\begin{array}{r}-4628.39 \\
0.27\end{array}$ & $\begin{array}{r}-15163.19 \\
0.001\end{array}$ & $\begin{array}{r}-16309.07 \\
0.01\end{array}$ & $\begin{array}{r}-2376.72 \\
0.03\end{array}$ & $\begin{array}{r}-2226.07 \\
0.10\end{array}$ & $\begin{array}{r}1986.92 \\
0.06\end{array}$ & $\begin{array}{r}1889.71 \\
0.12\end{array}$ \\
\hline $\mathrm{P}(\mathrm{F} /$ Chi-sq. $)$ & 0.00 & 0.00 & 0.00 & 0.00 & 0.00 & 0.00 & 0.00 & 0.00 \\
\hline R-squared & 0.91 & 0.89 & 0.95 & 0.92 & 0.99 & 0.99 & 0.96 & 0.94 \\
\hline D-W Statistics & & 0.44 & & 0.91 & & 2.14 & & 0.80 \\
\hline Q/Q' & $\begin{array}{l}0.001 \\
0.00\end{array}$ & $\begin{array}{c}-0.002 \\
0.91\end{array}$ & $\begin{array}{l}0.001 \\
0.00\end{array}$ & $\begin{array}{l}0.005 \\
0.00\end{array}$ & $\begin{array}{l}0.001 \\
0.00\end{array}$ & $\begin{array}{l}0.002 \\
0.31\end{array}$ & $\begin{array}{l}0.00 \\
0.39\end{array}$ & $\begin{array}{c}-0.001 \\
0.84\end{array}$ \\
\hline $\mathrm{AC}$ & $\begin{array}{r}1108.45 \\
0.003\end{array}$ & $\begin{array}{r}-293.43 \\
0.59\end{array}$ & $\begin{array}{r}2253.22 \\
0.00\end{array}$ & $\begin{array}{r}-581.45 \\
0.00\end{array}$ & $\begin{array}{r}154.10 \\
0.79\end{array}$ & $\begin{array}{r}-447.20 \\
0.63\end{array}$ & $\begin{array}{r}718.74 \\
0.07\end{array}$ & $\begin{array}{r}390.83 \\
0.26\end{array}$ \\
\hline $\begin{array}{l}\mathrm{AC} * \\
\log (\mathrm{Q})\end{array}$ & $\begin{array}{r}-55.28 \\
0.23\end{array}$ & $\begin{array}{r}-3.03 \\
0.97\end{array}$ & $\begin{array}{r}-88.40 \\
0.04\end{array}$ & $\begin{array}{r}-24.39 \\
0.47\end{array}$ & $\begin{array}{r}-171.41 \\
0.00\end{array}$ & $\begin{array}{r}-125.44 \\
0.00\end{array}$ & $\begin{array}{r}-157.17 \\
0.00\end{array}$ & $\begin{array}{r}-148.93 \\
0.00\end{array}$ \\
\hline $\begin{array}{l}\mathrm{AC}^{*} \\
\log (\mathrm{W} 1)\end{array}$ & $\begin{array}{r}46.32 \\
0.00\end{array}$ & $\begin{array}{r}42.11 \\
0.00\end{array}$ & $\begin{array}{r}49.64 \\
0.00\end{array}$ & $\begin{array}{r}43.20 \\
0.00\end{array}$ & $\begin{array}{r}31.50 \\
0.00\end{array}$ & $\begin{array}{r}29.79 \\
0.00\end{array}$ & $\begin{array}{r}18.99 \\
0.00\end{array}$ & $\begin{array}{r}18.51 \\
0.00\end{array}$ \\
\hline $\begin{array}{l}\mathrm{AC}^{*} \\
\log (\mathrm{W} 2)\end{array}$ & $\begin{array}{r}-336.05 \\
0.28\end{array}$ & $\begin{array}{r}160.32 \\
0.74\end{array}$ & $\begin{array}{r}-732.03 \\
0.05\end{array}$ & $\begin{array}{r}369.78 \\
0.17\end{array}$ & $\begin{array}{r}87.05 \\
0.37\end{array}$ & $\begin{array}{r}138.03 \\
0.38\end{array}$ & $\begin{array}{r}39.68 \\
0.42\end{array}$ & $\begin{array}{r}82.23 \\
0.05\end{array}$ \\
\hline P (F/Chi-sq.) & 0.00 & 0.00 & 0.00 & 0.00 & 0.00 & 0.00 & 0.00 & 0.00 \\
\hline R-squared & 0.98 & 0.97 & 0.99 & 0.996 & 0.996 & 0.98 & 0.98 & 0.96 \\
\hline D-W Statistics & & 2.05 & & 2.37 & & 2.43 & & 2.13 \\
\hline $\mathrm{N}(\mathrm{obs})$ & 32 & 32 & 22 & 22 & 26 & 26 & 38 & 38 \\
\hline Theta & $\begin{array}{l}0.14 \\
0.003\end{array}$ & $\begin{array}{c}-0.002 \\
0.91\end{array}$ & $\begin{array}{r}-0.14 \\
0.01\end{array}$ & $\begin{array}{l}0.005 \\
0.00\end{array}$ & $\begin{array}{l}0.07 \\
0.01\end{array}$ & $\begin{array}{l}0.002 \\
0.31\end{array}$ & $\begin{array}{r}-0.06 \\
0.00\end{array}$ & $\begin{array}{c}-0.001 \\
0.84\end{array}$ \\
\hline
\end{tabular}

Note: Standard errors recorded in italics below coefficient estimates. For 2SLS, Q' equals theta. For SUR, theta is calculated using regression estimates, and p-values of two-sided t-statistics are reported. R-squared statistics are adjusted. 
Table 6: Rosse-Panzar Test Results for Germany and the United States

\begin{tabular}{|c|c|c|c|c|c|c|c|}
\hline \multirow[t]{2}{*}{ Variable } & \multicolumn{2}{|c|}{$\begin{array}{l}\text { Germany } \\
1882-1913\end{array}$} & \multirow{2}{*}{$\begin{array}{c}\text { Germany } \\
1892-1913 \\
\text { OLS }\end{array}$} & \multicolumn{2}{|c|}{$\begin{array}{c}\text { US } \\
1888-1925\end{array}$} & \multicolumn{2}{|c|}{$\begin{array}{c}\text { US } \\
1892-1913\end{array}$} \\
\hline & OLS & $\begin{array}{c}\text { Prais- } \\
\text { Winston }\end{array}$ & & OLS & $\begin{array}{c}\text { Prais- } \\
\text { Winston }\end{array}$ & OLS & $\begin{array}{c}\text { Prais- } \\
\text { Winston }\end{array}$ \\
\hline TA & 0.17 & 0.36 & 1.39 & 2.64 & 2.65 & 3.32 & 3.29 \\
\hline Total assets & 0.72 & 0.57 & 0.01 & 0.00 & 0.00 & 0.00 & 0.00 \\
\hline MKT & 0.67 & 0.41 & -0.39 & -1.37 & -1.68 & -2.15 & -2.11 \\
\hline Total deposits & 0.09 & 0.42 & 0.38 & 0.02 & 0.00 & 0.00 & 0.00 \\
\hline W1 & -0.01 & 0.001 & 0.04 & 0.06 & 0.005 & -0.02 & -0.07 \\
\hline Deposit rate & 0.72 & 0.97 & 0.84 & 0.05 & 0.73 & 0.85 & 0.45 \\
\hline W2 & -1.51 & -0.61 & -0.17 & -0.64 & 0.13 & 0.76 & 0.65 \\
\hline Wage rate & 0.11 & 0.58 & 0.87 & 0.00 & 0.36 & 0.21 & 0.21 \\
\hline \multirow[t]{2}{*}{ Constant } & -2.08 & 0.46 & -3.24 & -1.66 & -4.3 & -10.96 & -10.05 \\
\hline & 0.15 & 0.80 & 0.17 & 0.30 & 0.02 & 0.08 & 0.01 \\
\hline P(F/Chi-sq.) & 0.00 & 0.00 & 0.00 & 0.00 & 0.00 & 0.00 & 0.00 \\
\hline Adjusted R-squared & 0.96 & 0.92 & 0.97 & 0.96 & 0.87 & 0.97 & 0.98 \\
\hline D-W statistic & 1.40 & 2.02 & 2.77 & 0.59 & 2.33 & 1.08 & 1.95 \\
\hline
\end{tabular}

Note: All variables are in natural logs. Standard errors are reported in italics below coefficient estimates. 
Table 7. Rates of Return and Rate Differentials

\begin{tabular}{|c|c|c|c|c|c|}
\hline Variables & $\begin{array}{l}\text { Germany } \\
1882-1913\end{array}$ & $\begin{array}{c}\text { US } \\
1888-1913\end{array}$ & $\begin{array}{c}\text { UK } \\
1888-1913\end{array}$ & $\begin{array}{l}\text { means test } \\
\text { US v. } \\
\text { Germany }\end{array}$ & $\begin{array}{l}\text { means test } \\
\text { US v. UK }\end{array}$ \\
\hline $\begin{array}{l}\text { ROA } \\
\text { net profits (percent of total assets) }\end{array}$ & $\begin{array}{l}2.44 \\
0.69\end{array}$ & $\begin{array}{l}1.67 \\
0.39\end{array}$ & & 0.00 & \\
\hline $\begin{array}{l}\text { ROE } \\
\text { net profits (percent of total capital } \\
\text { accounts) }\end{array}$ & $\begin{array}{l}7.67 \\
1.63\end{array}$ & $\begin{array}{l}7.35 \\
1.62\end{array}$ & $\begin{array}{l}5.76 \\
1.52\end{array}$ & 0.24 & 0.00 \\
\hline ROA - riskfree rate & $\begin{array}{r}-1.01 \\
0.66\end{array}$ & $\begin{array}{r}-0.58 \\
0.65\end{array}$ & & 0.01 & \\
\hline ROE - riskfree rate & $\begin{array}{l}4.22 \\
1.61\end{array}$ & $\begin{array}{l}5.10 \\
1.96\end{array}$ & $\begin{array}{l}2.96 \\
1.51\end{array}$ & 0.04 & 0.00 \\
\hline ROE - loan rate & $\begin{array}{l}1.58 \\
1.86\end{array}$ & $\begin{array}{l}1.51 \\
1.67\end{array}$ & $\begin{array}{l}2.33 \\
1.42\end{array}$ & 0.44 & 0.03 \\
\hline ROE - deposit rate & $\begin{array}{l}5.55 \\
1.73\end{array}$ & $\begin{array}{l}5.64 \\
1.53\end{array}$ & $\begin{array}{l}3.81 \\
1.43\end{array}$ & 0.42 & 0.00 \\
\hline Loan rate - Deposit rate & $\begin{array}{l}3.97 \\
0.34\end{array}$ & $\begin{array}{l}4.13 \\
0.54\end{array}$ & $\begin{array}{l}1.48 \\
0.09\end{array}$ & 0.00 & 0.00 \\
\hline
\end{tabular}

Note: Standard deviations are recorded in italics below means. Reported p-values are based on a one-sided $\mathrm{t}$-test that the larger mean is significantly larger than the smaller mean. Means tests are based on years in which both countries have available data. 


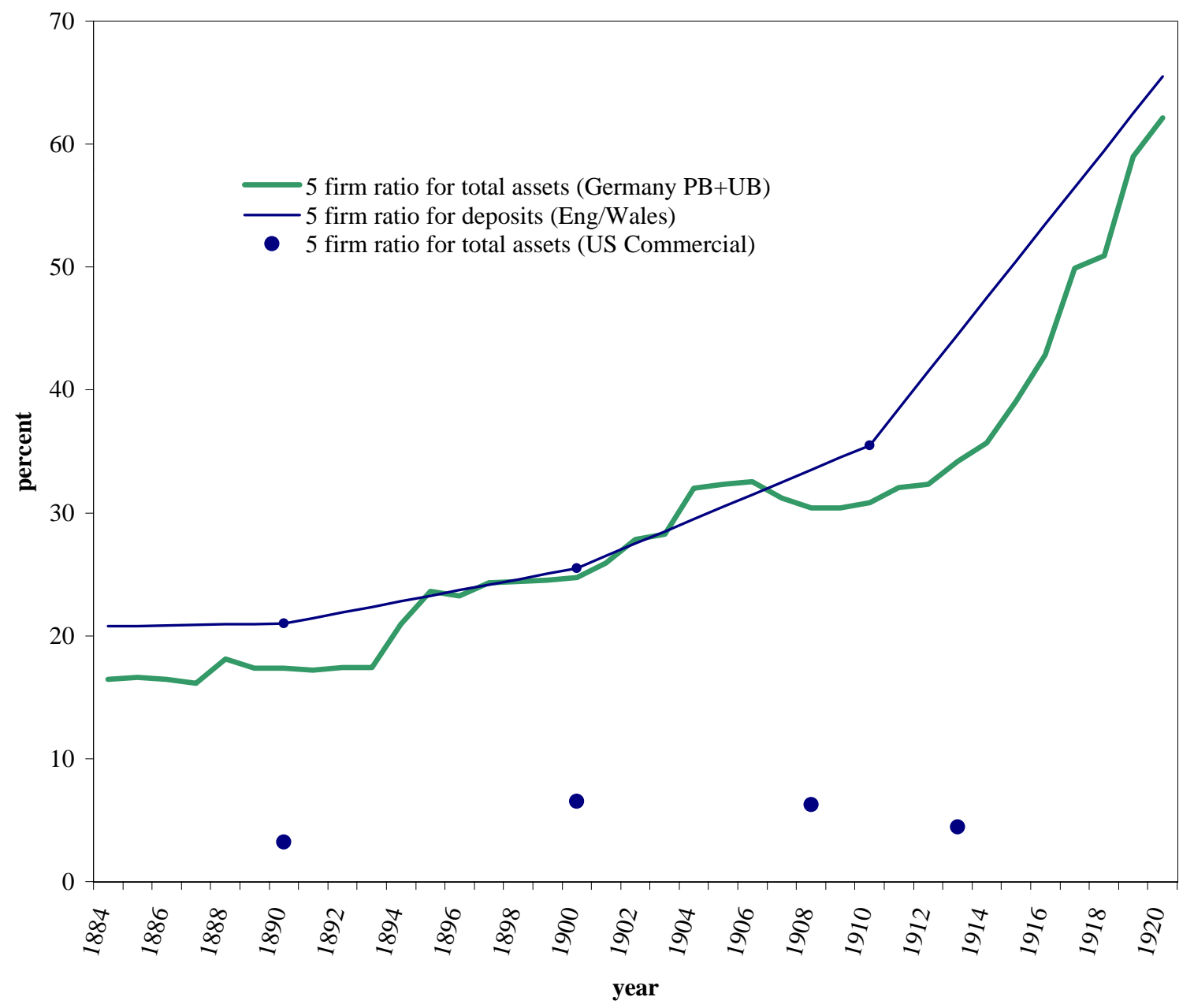

Figure 1. Banking Concentration in Germany, England, and the US, 1884-1920

Sources : calculated from Deutsche Bundesbank (1976), Saling's (various years), Handbuch der deutschen Aktiengesellschaften (various years), Goldsmith (1969), Capie and Rodrik-Bali (1982), and U.S. Comptroller of the Currency (various years). 


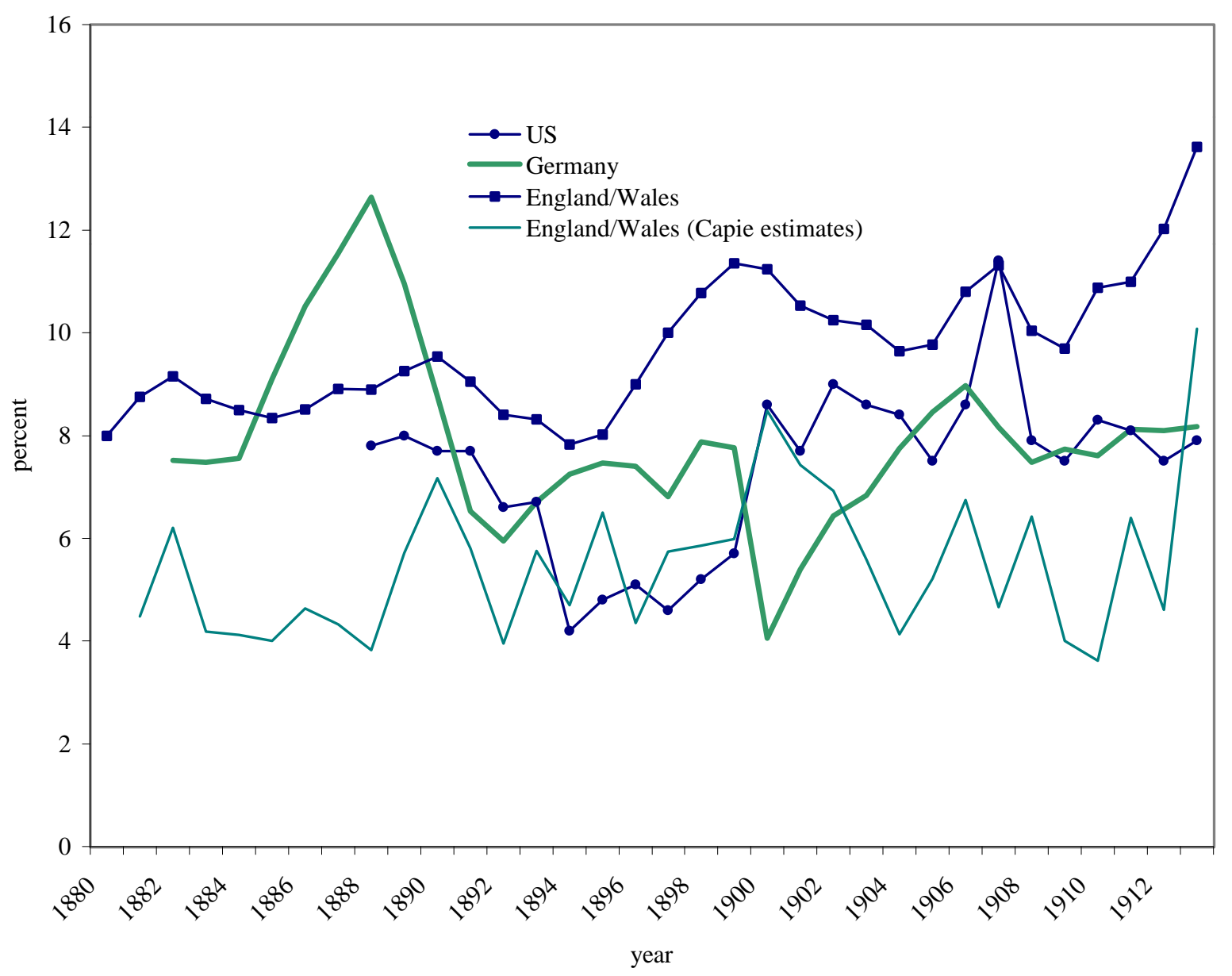

Figure 2. Return on Equity of Commercial Banks, 1880-1913

Sources: England/Wales, Capie (1988); Germany, calculated from Saling's and Handbuch der deutschen Aktiengesellschaften (various years); and US, Historical Statistics of the US. 


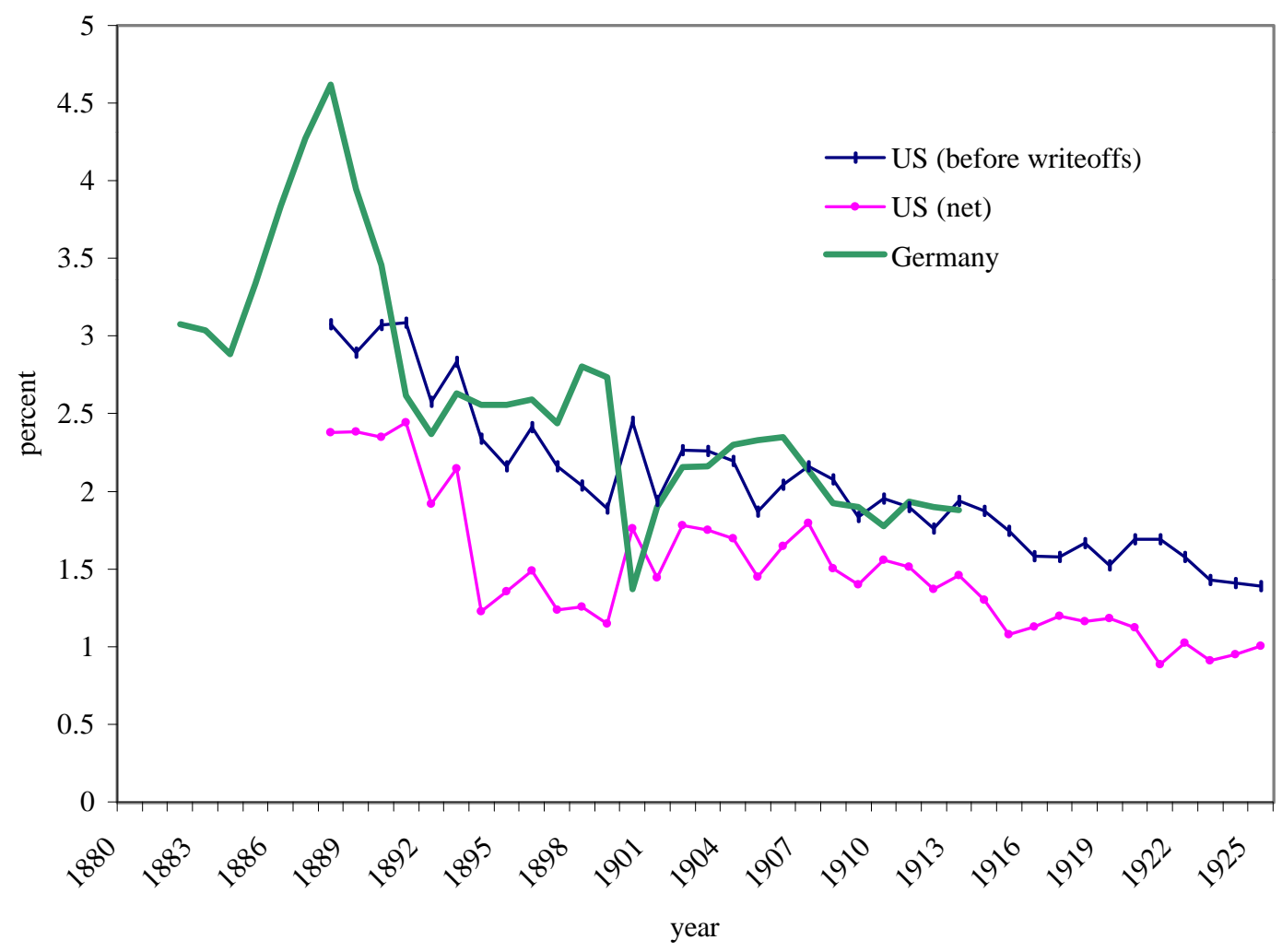

Figure 3. Return on Assets of Commercial Banks, 1880-1925

Sources: England/Wales, Capie (1988); Germany, calculated from Saling's and Handbuch der deutschen Aktiengesellschaften (various years); and US, Historical Statistics of the US. 


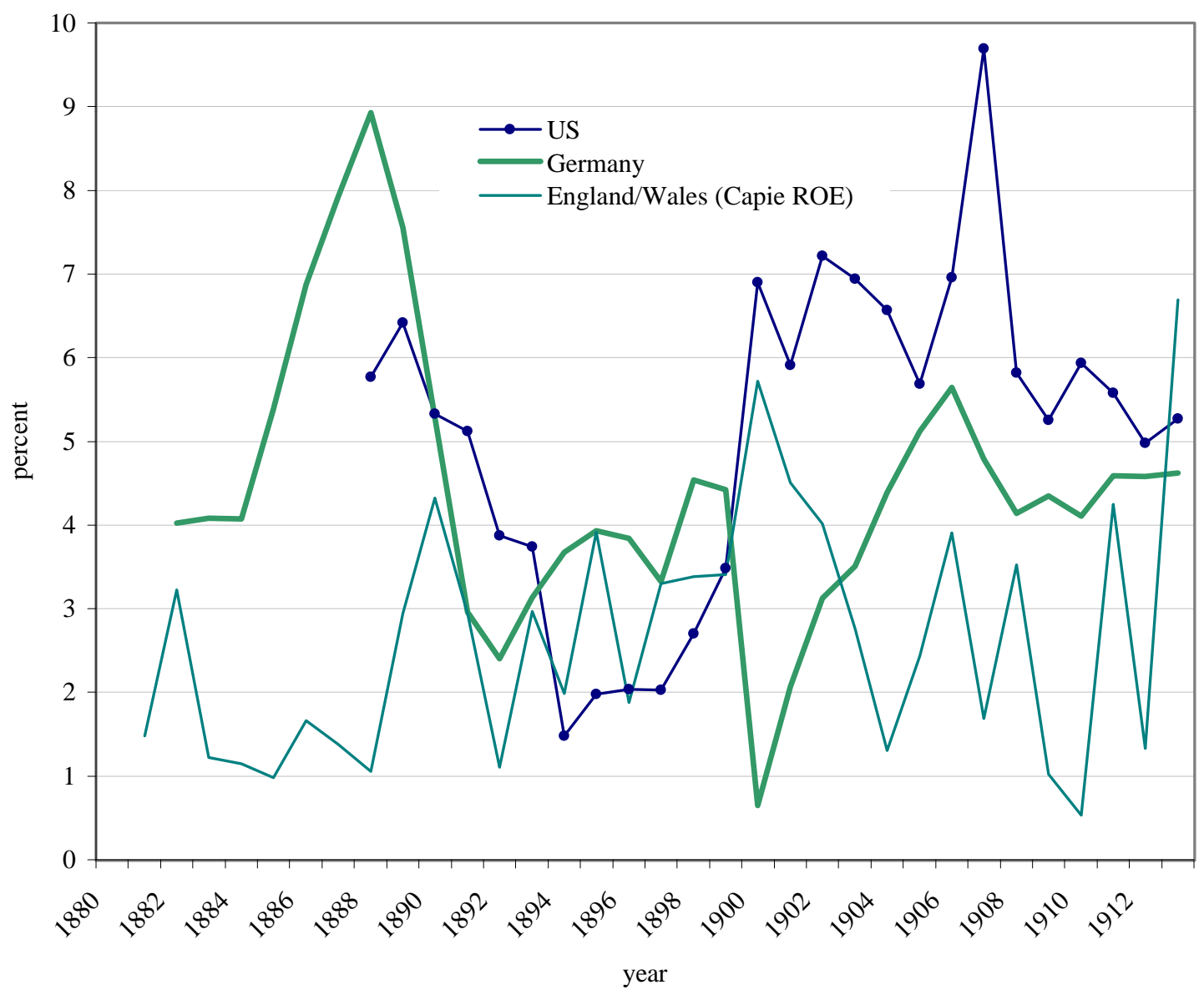

Figure 4. ROE in Excess of Risk-Free Rate, 1880-1913

Sources: England/Wales, Capie (1988); Germany, calculated from Saling's and Handbuch der deutschen Aktiengesellschaften (various years); and US, Historical Statistics of the US . 